\title{
2. MIOCENE RADIOLARIAN BIOSTRATIGRAPHY OF THE DÉCOLLEMENT ZONE (NORTHERN BARBADOS RIDGE) ${ }^{1}$
}

\author{
Torsten Steiger ${ }^{2}$
}

\begin{abstract}
The décollement zone of the Lesser Antilles Volcanic Arc, drilled during Ocean Drilling Program Leg 156, contains soft radiolarian-bearing clayey lithologies. In the upper part of this zone, radiolarians are abundant; in the lower part, they are rare. Radiolarian preservation ranges from excellent (Hole 949B) to moderate and highly recrystallized (Hole 948C). The radiolarian faunas are of early Miocene age. The assemblages could be attributed to early early Miocene radiolarian zones (Lychnocanoma elongata Zone and Cyrtocapsella tetrapera Zone) and late early Miocene zones (Stichocorys delmontensis Zone, Stichocorys wolffii Zone, and Calocycletta costata Zone). In the lithologic column the radiolarian zones are separated by hiatuses associated with color changes, breccia horizons, and shear zones that are represented by intervals with rich scaly fabric. Occasional reworking of Miocene through late Eocene radiolarians can be observed. At the top and in the middle of the décollement, radiolarians are diagenetically recrystallized. In these zones, abundance and diversity is strongly reduced. Diagenetically stable forms are orosperids ("fat rad zone") and large nassellarians like Cyclampterium and Calocycletta.
\end{abstract}

\section{INTRODUCTION}

The décollement zone of the Lesser Antilles Volcanic Arc was the subject of the Ocean Drilling Program (ODP) Leg 156 drilling project. The northern Barbados Ridge was previously drilled during Deep Sea Drilling Project (DSDP) Leg 78A (Biju-Duval, Moore, et al. 1984) and ODP Leg 110 (Mascle, Moore, et al., 1988). East of the studied area, Site 27 of DSDP Leg 4 (Bader, Gerard, et al., 1970) penetrated into the normal sedimentary sequence of the Atlantic Ocean. Radiolarian investigations have been published by Renz (1984) from Sites 541 and 543 of Leg 78A.

Radiolarians were recovered from Sites 948 and 949. The holes containing radiolarian-bearing sediments are Hole 948C and Holes 949B and 949C (Shipley, Ogawa, Blum, et al., 1995). The location of Holes 948A and 948C almost correspond to Hole 671B of Leg 110. Site 541 (Leg 78A) is about $1 \mathrm{~km}$ southeast of Site 949, representing a different tectonic setting. Site 949 is situated about $2 \mathrm{~km}$ west of the deformation front. There is no previous drill site close to this area. Hole 675A (Leg 110) is about $1.5 \mathrm{~km}$ south of Site 949.

Leg 156 holes were drilled entirely in the area of the accretionary prism of the Lesser Antilles Volcanic Arc (Shipley, Ogawa, Blum, et al., 1995). Main objectives were to investigate the rates, quantities, and intervals of fluid migration and their effects in the sedimentary environment and along the tectonic structures within the décollement and the overlying accretionary prism. Therefore, biostratigraphic repetition and biostratigraphic hiatuses formed by tectonic influence were expected.

The most important purpose of the paleontologic work was to separate segments of biostratigraphic continuity and compare their vertical distribution with the pattern of shear zones. Because calcareous material is completely absent within the décollement zone, radiolarians became the most important fossils for dating sedimentary intervals.

${ }^{1}$ Shipley, T.H., Ogawa, Y., Blum, P., and Bahr, J.M. (Eds.), 1997. Proc. ODP, Sci. Results, 156: College Station, TX (Ocean Drilling Program).

'Gratrather Straßse 53a, 82
$100425.1104 @$ compuserve. com
The radiolarians of the décollement zone show specific features of recrystallization and diagenesis. They are closely related to the biostratigraphic hiatuses as well as to the tectonic shear zones (Steiger et al., in press).

Locations of the Leg 156 drill sites are furnished below:

$\begin{array}{ccccc}\text { Hole } & \begin{array}{c}\text { Water depth } \\ (\mathbf{m})\end{array} & \text { Position } & \begin{array}{c}\text { Recovery } \\ (\mathbf{m})\end{array} & \text { Cores } \\ & & & \\ 948 \mathrm{C} & 4931.5 & 15^{\circ} 31.568^{\prime} \mathrm{N}, 58^{\circ} 43.935^{\prime} \mathrm{W} & 171.46 & 19 \\ 949 \mathrm{~B} & 5004.7 & 15^{\circ} 32.214^{\prime} \mathrm{N}, 58^{\circ} 42.855^{\prime} \mathrm{W} & 2.18 & 25\end{array}$

\section{PROCEDURES}

Dry samples averaging $20 \mathrm{~cm}^{3}$ in size were disaggregated with hydrogen peroxide. The material was washed with distilled water and cleaned in an ultrasonic bath several times to remove the clay. After decanting, the sample was dried, then sieved and split into three grain-size fractions. The fractions used are $0-63 \mu \mathrm{m}, 63-250 \mu \mathrm{m}$, and more than $250 \mu \mathrm{m}$.

Radiolarian analysis is based on the observation of strewn slides. The radiolarian skeletons are randomly strewn on a glass slide and fixed with an ultraviolet active glue, and covered with a cover glass.

Quantities are estimated from the whole amount of radiolarian material compared to the entire sediment sample. The abundance of forms is calculated from the strewn slides. Quantitative categories are $\mathrm{R}=$ rare, $\mathrm{F}=$ few, and $\mathrm{C}=$ common.

The biostratigraphy zonation is based on the zonations of Riedel and Sanfilippo (1978) and Sanfilippo et al. (1985), and the compilation of Cenozoic radiolarian biostratigraphy for low and middle latitudes of C. Nigrini and A. Sanfilippo (in press), mostly based on Riedel and Sanfilippo (1978) and Sanfilippo et al. (1985) for Miocene taxa).

\section{HOLE 948C Lithologic Setting}

The lithologies of Site 648 are composed of three main intervals. The upper part (lithologic Units I through IID) consists of calcareous 
ooze and claystones of the accretionary prism. Recent radiolarians occur in Core 156-948C-1H (lithologic Unit I). Downcore, no radiolarians are present in the accretionary prism (lithologic Units IIA through IID). Radiolarians start again in Section 156-948C-10X-1, which is the uppermost part of the décollement zone (lithologic Unit IIE). Pinkish and brownish gray claystones contain an early Miocene to early middle Miocene fauna of varying abundances, diversity, and preservation. Radiolarians can be detected down to the base of the décollement zone (Core 156-948C-12X), which is composed of olivebrown and grayish brown claystones (lithologic Unit IIF) and banded variegated claystones (lithologic Unit IIIA; see Shipboard Scientific Party, 1995).

\section{Radiolarian Age and Zonation}

Recognition of radiolarian zones depends on the completeness of time-specific associations. Frequently, the strewn-slide analyses indicate that numerous faunal compositions are mixed, containing reworked specimens. The sequence of radiolarian intervals separated by hiatuses shows that radiolarian associations of the Calocycletta costata Zone alternate with assemblages of the Stichocorys wolffii Zone. Only one section is composed of radiolarian of the Cyrtocapsella tetrapera Zone and the Lychnocanoma elongata Zone in the lower part of the décollement zone. This interval is located just above the so-called "fat rad zone," which is dominated by strongly recrystallized orospherid forms.

A second interval with recrystallized radiolarians is situated in the uppermost part of the décollement zone (see Steiger et al., in press). Between the zones where radiolarians are recrystallized, all faunas are well preserved. Abundances are high in the upper part of the décollement zone above the "fat rad zone." In the lower part diversity and abundances decrease but preservation remains.

The radiolarian zonation of Hole 156-948C is composed as follows (Fig. 1):

1. Recrystallized interval. Starting with Sample 156-948C-10X1, 42-44 cm, through Sample 156-948C-10X-1, 143-145 cm, radiolarians are extremely recrystallized. Only robust growth forms and some genera could vaguely be determined. Identifiable forms are Calocycletta and Didymocyrtis. Therefore, this interval probably is Miocene in age.

2. Interval containing transition from Stichocorys wolffii Zone to Calocycletta costata Zone. This interval includes Sample 156948C-10X-2, 69-71 cm, through Sample 156-948C-10X-3, $25-27 \mathrm{~cm}$. The radiolarian assemblage is mostly composed of Cyrtocapsella cornuta, Liriospyris stauropora, Liriospyris parkerae, Dorcadospyris dentata, and Stichocorys wolffii. Although Calocycletta costata is missing, the fauna characterizes the transition between the Stichocorys wolffii Zone and the Calocycletta costata Zone of late Miocene age.

3. Interval from upper to lower Stichocorys wolffi Zone. Between Sample 156-948C-10X-3, 37-39 cm, and Sample 156948C-10X-5, 22-24 cm, radiolarians indicate the Stichocorys wolffi Zone. Downsection, the transition from the upper part of the Stichocorys wolfii Zone to the lower part can be recognized. Stichocorys wolffii, Cyrtocapsella cornuta, Cyrtocapsella tetrapera, Liriospyris stauropora, and Dorcadospyris dentata characterize the younger part of the zone. In the middle of this interval, Calocycletta serrata occurs and seems to be reworked. The older part of the Stichocorys wolffi Zone contains Dorcadospyris ateuchus.

4. Interval from upper to lower Calocycletta costata Zone. From Sample 156-948C-10X-5, 45-47 cm, through Sample 156948C-10CC, 1-3 cm, Calocycletta costata is the most agediagnostic fossil. The upper part of the sequence contains Liriospyris parkerae, the lower part is further characterized by
Lychnocanoma elongata, Didymocyrtis prismatica, and Calocycletta serrata, the latter probably being reworked.

5. Interval containing the transition from Stichocorys wolffii Zone to the Calocycletta costata Zone. Downcore from Sample 156-948C-10CC, 16-18 cm, through Sample 156-948C-11X$1,2-4 \mathrm{~cm}$, Calocycletta costata is not present. The rest of the fauna is dominated by the occurrence of Stichocorys wolffii, Dorcadospyris dentata, Didymocyrtis prismatica, Cyrtocapsella cornuta, and Cyrtocapsella tetrapera.

6. Interval containing the upper Calocycletta costata Zone. Below a breccia layer, radiolarians of the Calocycletta costata Zone and abundant specimens of this species occur. The assemblage indicates the upper part of this zone because Liriospyris parkerae is present. The interval embraces Sample 156-948C-11X-1, 8-9 cm, through Sample 156-948C-11X-2, $2-4 \mathrm{~cm}$. At the base of the sequence just above a major lithologic break, Eocene radiolarians like Lithochytris vespertilio are reworked.

7. Interval containing the Cyrtocapsella tetrapera Zone. Below a tectonic structure characterized by a thick shear zone of scaly fabric and by manganese layers, radiolarian associations indicate early early Miocene age. In the upper part of the sequence Cyrtocapsella tetrapera, Didymocyrtis prismatica, and Calocycletta serrata are the most abundant species. The assemblage of the Cyrtocapsella tetrapera Zone occurs from Sample 156-948C-11X-2, 11-13 cm, through Sample 156-948C-11X$2,63-67 \mathrm{~cm}$.

8. Interval containing Lychnocanoma elongata. From Sample 156-948C-11X-2, 79-81 cm, through Sample 156-948C-11X2, 120-122 cm, Lychnocanoma elongata becomes more abundant. In addition the presence of Dorcadospyris ateuchus indicates earliest radiolarian zone of the Miocene. This interval shows increasing intensity of radiolarian recrystallization and reduction of species diversity.

The intervals containing radiolarians of the Cyrtocapsella tetrapera Zone and the Lychnocanoma elongata Zone are separated by a thick zone of scaly fabric. The entire lithologic sequence of the early early Miocene contains numerous shear zones of considerable thickness. All these zones probably create minor biostratigraphic breaks.

9. Recrystallized interval: "Fat rad Zone." Below a very thick shear zone, a 3-m-thick, undisturbed section occurs. This interval contains strongly recrystallized radiolarians. The radiolarians are only represented by large spheres belonging to spumellarians of the Orosphaera type. The transition between the "fat rad zone" and parts of the lower interval could not be investigated because a whole-round sample was taken at this place.

10. Interval containing the Calocycletta costata Zone. From the top of Section 156-948C-11X-5 downcore, radiolarians are generally rare. They indicate the Calocycletta costata Zone of late early Miocene. Below Sample 156-948C-12-3, 30-32 cm, radiolarians could not be assigned to a Miocene radiolarian zone.

\section{Vertical Distribution of Radiolarian Zones and Comparison with Shear Zone Pattern}

Radiolarian zones are vertically distributed as follows:

1. The top of the décollement contains a layer of pinkish gray claystones with ash layers and brecciated intervals. Here radiolarians are strongly recrystallized.

2. Below the layer of strong recrystallization an interval of abundant well-preserved radiolarians occurs. The faunas are of late early Miocene age. Internally, the section is divided into bio- 


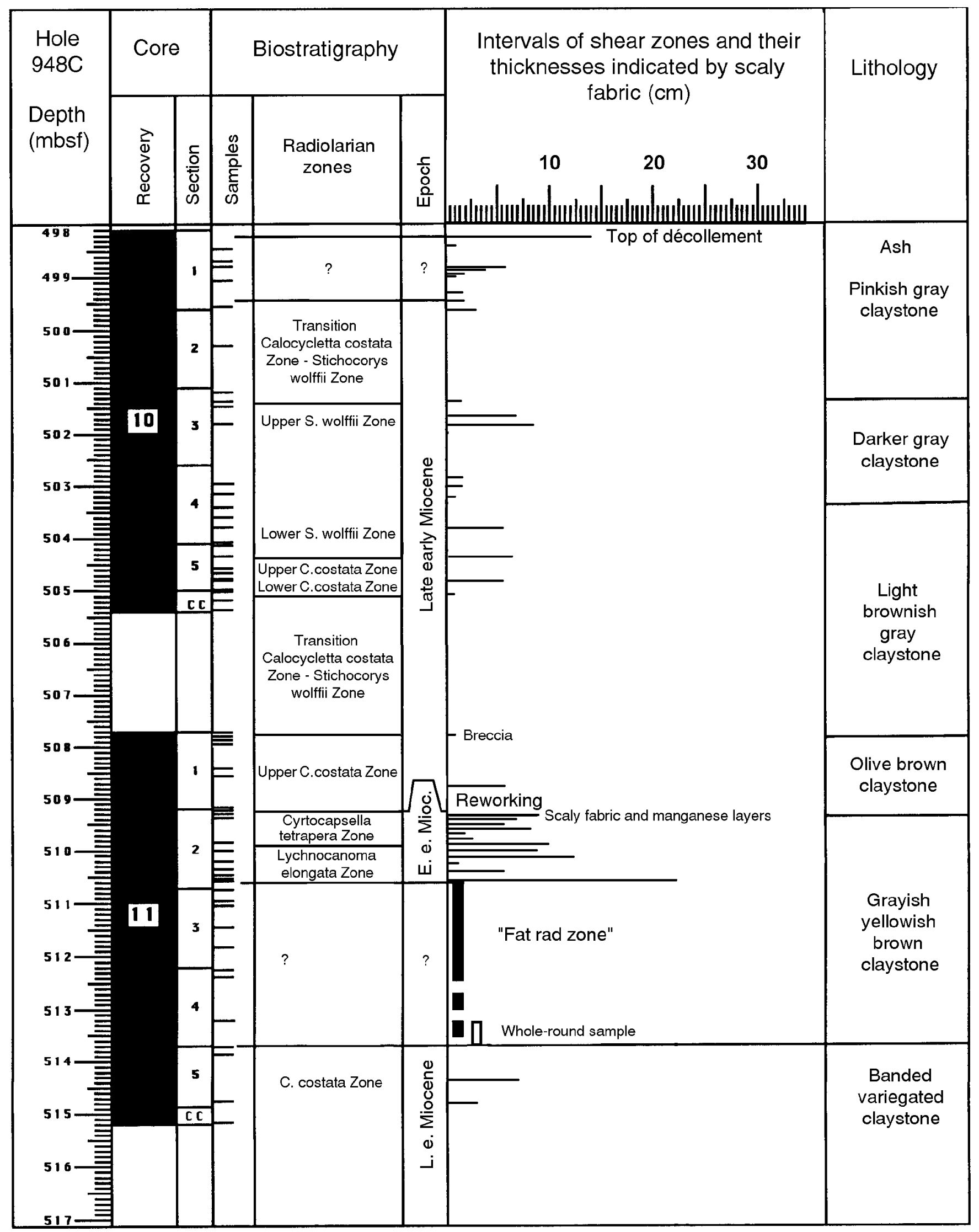

Figure 1. Radiolarian zonation for Hole 948C compared with position and thicknesses of shear zones characterized by scaly fabric. 
stratigraphic levels ranging from the Stichocorys wolffii Zone to the Calocycletta costata Zone. The assemblages indicate uppermost early Miocene age but they apparently do not pass the boundary to the middle Miocene. Most of the wellpreserved radiolarians of the upper part of the section are mechanically broken, which indicates internal brecciation of the sediment.

3. The Stichocorys delmontensis Zone is missing, although some specimens of this species occur. The radiolarian assemblages, however, are more likely to belong to the Stichocorys wolffii Zone.

4. The late early Miocene radiolarian zones are underlain by an early early Miocene section composed of the Cyrtocapsella tetrapera Zone and the Lychnocanoma elongata Zone. In this part of the décollement the radiolarian tests are increasingly recrystallized downcore.

5. In the "fat rad zone," only large spherical bodies of recrystallized radiolarians are embedded in the grayish yellowish brown claystone. Maximum size of the tests is $2 \mathrm{~mm}$. These forms can be attributed to orosphaerids, which also occur in samples with well-preserved radiolarians. In unrecrystallized faunas, orosphaerids are broken. In the "fat rad zone," they are intact, because of an intense cementation and recrystallization of the tests into quartz (Steiger et al., in press).

6. The lower boundary of the "fat rad zone" is not documented, because a whole-round sample for chemical research was taken in this interval. Below this zone radiolarians are again well preserved. In contrast to the rich intervals above, radiolarians of the lower part of the décollement zone are not abundant.

All biostratigraphic hiatuses can be attributed to shear zones that commonly appear in the lithologic column of the décollement zone. Major biostratigraphic gaps are accompanied by thicker zones of scaly fabric or by breccias (Table 1).

Sediments containing radiolarians of older biostratigraphic zones (Cyrtocapsella tetrapera Zone and Lychnocanoma elongata Zone) are intensely sheared. The contact with the "fat rad zone" is characterized by a very thick interval of scaly fabric of more than $20 \mathrm{~cm}$. The "fat rad zone" itself is undisturbed.

\section{HOLES 949B AND 949C Lithologic Setting}

Site 949 is located $2 \mathrm{~km}$ west of the deformation front. The holes were drilled in extremely soft sediments of the décollement zone. Recovery, therefore, was very low. Radiolarians occur in Core 156949B-19X through Core 156-949B-22X. Lithologies consist of light brownish gray to yellowish brown claystone (lithologic Unit IIE) and mottled variegated claystone (lithologic Unit III). The boundary between the lithologic Units IIE and III is located at $430.92 \mathrm{~m}$ in Core 156-949B-22X. In Cores 156-949B-20R and 156-949B-21X recovery is reduced to small fragments of material containing rich radiolarian faunas.

\section{RADIOLARIAN AGE AND ZONATION}

1. Normal sequence of late early Miocene age. In Core 156949B-19X radiolarians are well preserved. In Sample 156949B-19X-1, 12-16 cm, the association can be attributed to the Calocycletta costata Zone. From Sample 156-949B-19X$1,77-81 \mathrm{~cm}$, to Sample 156-949B-19X, 97-81 cm, the fauna assigned to the Stichocorys wolffii Zone. Sample 156-949B19X-3, 107-109 cm, to Sample 156-949B-21CC, biostratigraphic markers indicate the Stichocorys wolffii Zone. In
Cores 156-949B-20X and 156-949B-21X, diversity is reduced because of increasing diagenetic influence (Fig. 2).

2. Recrystallized interval. In Core 156-949B-22X, radiolarians are recrystallized as in the "fat rad zone" of Hole 948C. The age of the recrystallized interval is unknown.

3. Below the recrystallized interval radiolarian are well-preserved but rare. The amount of biostratigraphic markers is not high enough to assign the fauna to a distinct radiolarian zone. The taxa that are sufficiently time specific indicate early Miocene age.

\section{VERTICAL DISTRIBUTION OF RADIOLARIAN ZONES}

In contrast to Hole $948 \mathrm{C}$, Holes $949 \mathrm{~B}$ and $949 \mathrm{C}$ contained a thicker continuous interval of radiolarian zones. A biostratigraphic break or repetition is possibly present below the base of the recrystallized interval because of lithologic differences and changes in radiolarian preservation, abundance, and diversity. According to the intact biostratigraphic sequence, shear zones are less frequent and biostratigraphic hiatuses are not tied to intervals of scaly fabric (Table 2).

\section{DISCUSSION}

Renz (1984) reported first results about the faunal composition in the top part of the décollement zone. Here the biostratigraphic range comprised the Calocycletta costata Zone, and the Stichocorys delmontensis Zone. Between these zones a dissolution zone is responsible for the absence of the Stichocorys wolffii Zone. As Site 541 is about $1000 \mathrm{~m}$ southeast of Hole 948C, it is likely that the lithologic column differs considerably. With respect to the tectonic influence within the décollement zone, a change in the sequence of the hiatuses can be expected. The dissolution zone mentioned by Renz could correspond to a tectonically active interval comparable to a shear zone.

Preservation of the radiolarians depends on the porosity and the content of pore water in the sediment. Hole $948 \mathrm{C}$ yielded a good recovery of sediments not very rich in pore water. Here, radiolarians are well preserved, but mostly fragmented. Mechanical shear and interporous abrasion must be responsible for this. Hole 949B is characterized by a poor recovery. The sediment is very soft and soupy. Radiolarian tests are well preserved and mechanical abrasion is weak.

In this sense, locations near the deformation front are not very affected by shear movements. Biostratigraphic hiatuses, therefore, are not developed as in Hole 948C.

The recrystallized intervals seem to be a major diagenetic phenomenon. If these zones form a continuous layer between Hole 948C ("fat rad zone") and Hole 949B, it would be an appropriate path for fluid transport (see scientific objectives of Leg 156 in Shipley, Ogawa, Blum et al., 1995), dipping upward about $80 \mathrm{~m}$ from west (Hole 948C) to east (Hole 949B). Radiolarians are affected by group-selective diagenesis characterized by a transformation from biogenic opal into zeolites (Steiger et al., in press).

\section{SYSTEMATIC PALEONTOLOGY}

\section{Artophormis gracilis Riedel}

Artophormis gracilis Riedel; Riedel, 1959, p. 300, pl. 2, figs. 12, 13. Artophormis gracilis Riedel; Moore, 1971, pl. 5, figs. 10, 11.

Artophormis gracilis Riedel; Sanfilippo et al., 1973, pl. 4, fig. 4

Artophormis gracilis Riedel; Sanfilippo, Westberg-Smith and Riedel, 1985, p. 666 , fig. 12,2 a-c.

Remarks: Rare in the transition between the Stichocorys wolffii Zone and Calocycletta costata Zone in Hole 949B. 
Table 1. Radiolarian biostratigraphic data for Hole 948C.

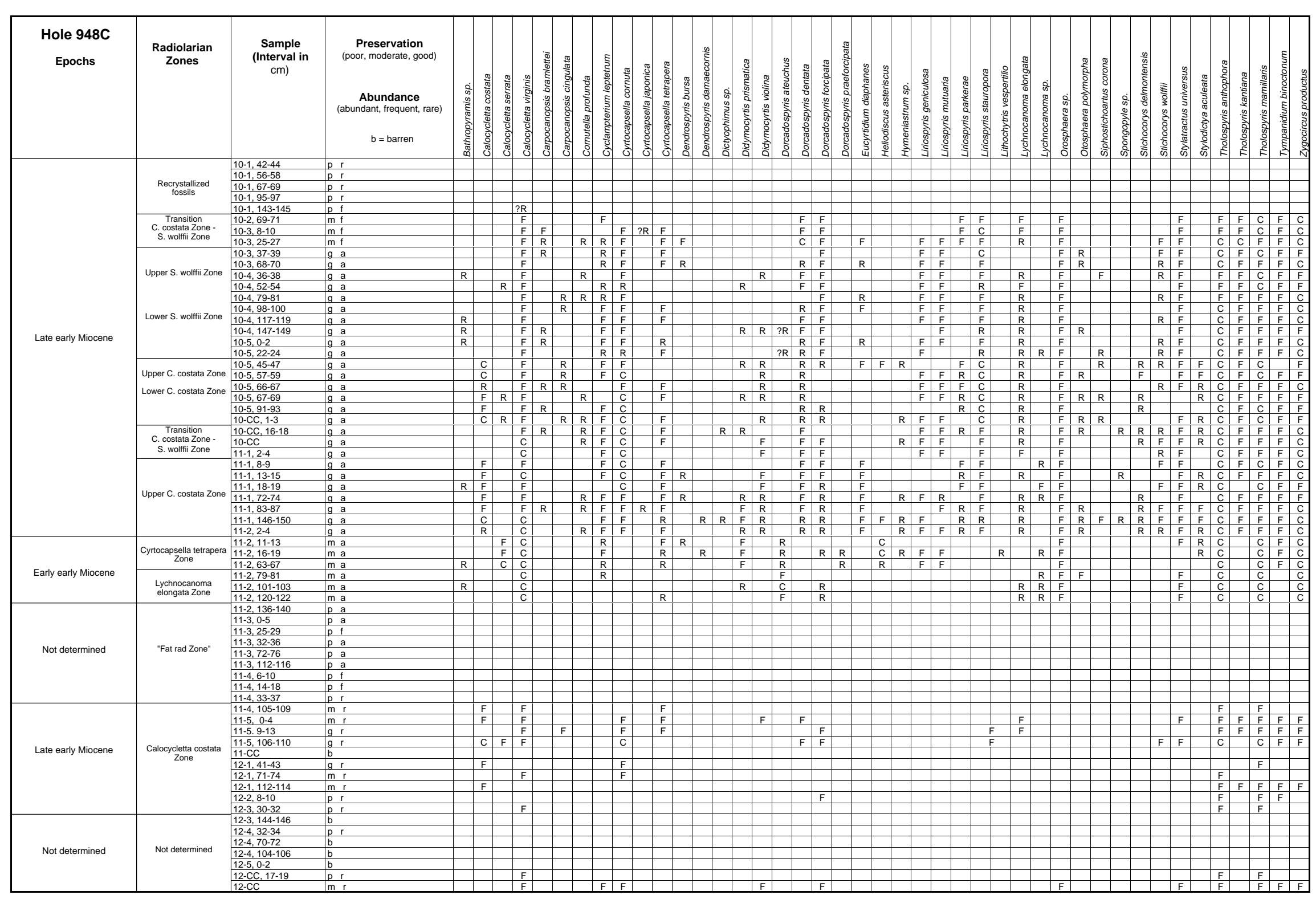




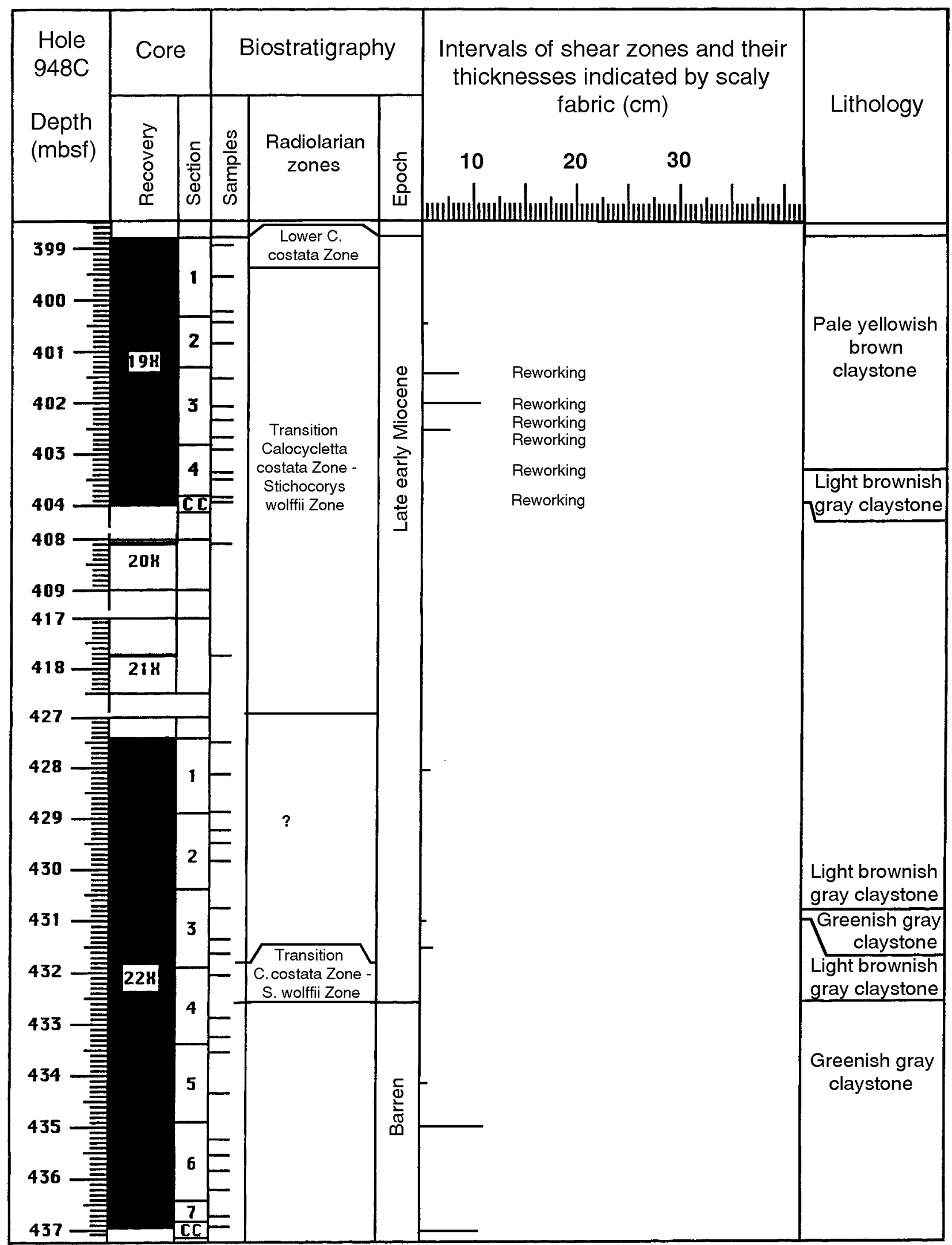

Figure 2. Radiolarian zonation for Hole 949B compared with position and thicknesses of shear zones characterized by scaly fabric. 
Table 2. Radiolarian biostratigraphic data for Hole 949B.

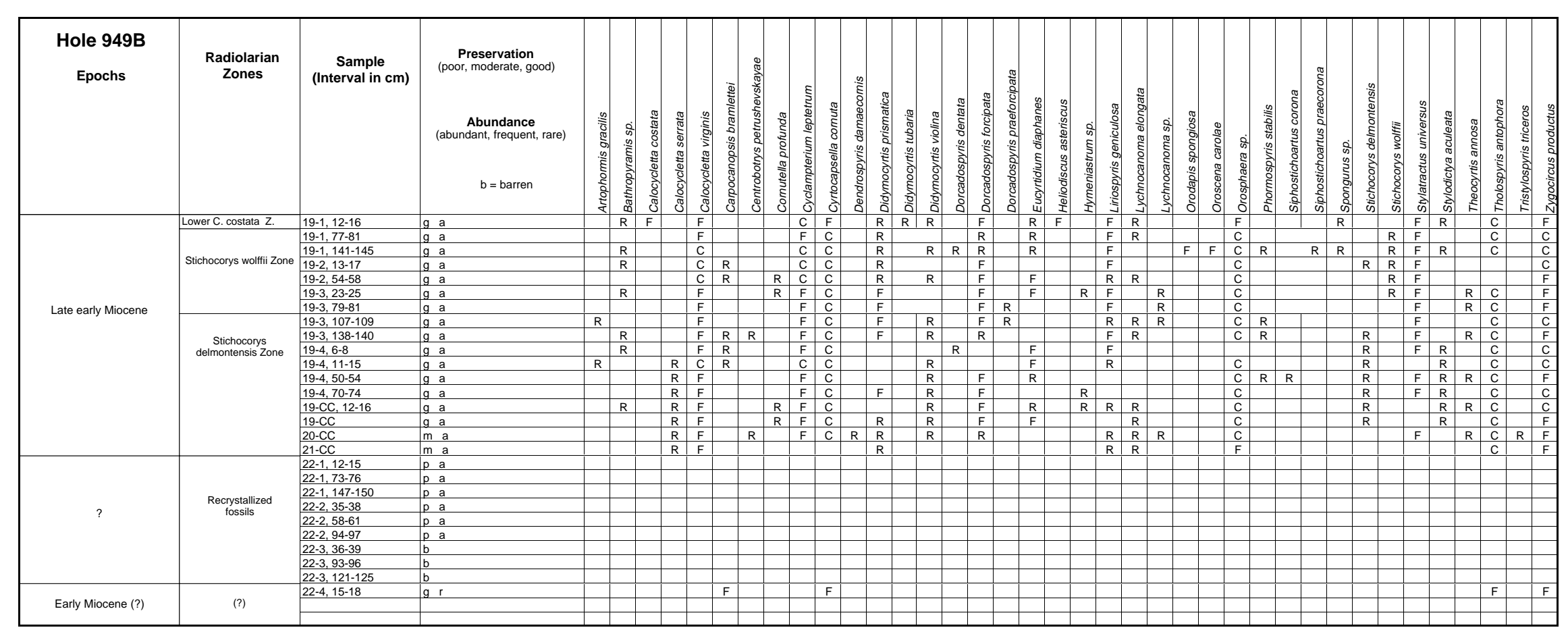


Bathropyramis sp. indet. (Pl. 4, Fig. 7)

Remarks: Rare, occurring as various morphotypes.

$$
\text { Calocycletta costata (Riedel) }
$$$$
\text { (Pl. 1, Figs. 1, 2) }
$$

Calocyclas costata Riedel; Riedel,1959, p. 296, pl. 2, fig. 9. Calocycletta costata (Riedel); Riedel and Sanfilippo, 1978, p. 66, pl. 3, fig. 9. Calocycletta costata (Riedel); Renz, 1984, p. 455, fig. 9.

Remarks: This species co-occurs with Calocycletta virginis (Haeckel). Most of the specimens have pronounced ridges between the pore rows. Rare tests show typical longitudinal pore rows, but without costae. These are perhaps transitional forms between Calocycletta costata (Riedel) and C. virginis (Haeckel) as expected by Riedel (1959). At the base of the occurrence Calocycletta serrata Moore is also present. Reasons for this may be reworking of some tests of Calocycletta serrata Moore or a longer duration of the occurrence of this species.

\section{Calocycletta serrata Moore}

$$
\text { (Pl. 1, Figs. 3, 4) }
$$

Calocycletta serrata Moore; Moore,1972, p. 148, pl. 2, figs. 1-3. Calocycletta serrata Moore; Riedel and Sanfilippo, 1978, p. 66, pl. 3, figs. 12.

Remarks: This species is common in the Cyrtocapsella tetrapera Zone. In Sample 156-948C-11X-2, 63-67 cm, it seems to create an acme at the base of the zone. The first occurrence of Calocycletta serrata Moore is reported by Riedel and Sanfilippo (1978) from the beginning of the Cyrtocapsella tetrapera Zone. The first occurrence of the species is dated at 21.2 Ma (Theyer et al., 1978)

\section{Calocycletta virginis Haeckel}

(Pl. 1, Figs. 5, 6)

Calocyclas (Calocycletta) virginis Haeckel; Haeckel, 1887, p. 1381, pl. 74, fig. 4.

Calocycletta virginis Haeckel; Riedel and Sanfilippo, 1978, p. 66, pl.3, figs. $13,14$.

Remarks: One of the most common species in the Leg 156 material. Feet are present or absent. Proportions of the abdomen occasionally tend to grade into these of Calocycletta robusta Moore.

\section{Carpocanopsis bramlettei Riedel and Sanfilippo}

Carpocanopsis bramlettei Riedel and Sanfilippo; Riedel and Sanfilippo, 1971, p. 1597 , pl. 2 G, figs. 8-14; pl. 8, fig. 7 .

Carpocanopsis bramlettei Riedel and Sanfilippo; Riedel and Sanfilippo, 1978, p. 67, pl. 4, fig. 6.

Remarks: Not very common in the late early Miocene radiolarian zones of both sites.

\section{Carpocanopsis cingulata Riedel and Sanfilippo}

Carpocanopsis cingulata Riedel and Sanfilippo; Riedel and Sanfilippo, 1971, p. 1597 , pl. 2 G, figs. $17-21$; pl. 8 , fig. 8 .

Carpocanopsis cingulata Riedel and Sanfilippo; Riedel and Sanfilippo, 1978, p. 67 , pl. 4 , fig. 4.

Remarks: Rare in the late early Miocene of both sites.

\section{Centrobotrys petrushevskayae Sanfilippo and Riedel}

Centrobotrys (?) sp. A Riedel and Sanfilippo; Riedel and Sanfilippo, 1971, p. 1602 , pl. 3F, figs. $15,16$.

Centrobotrys petrushevskayae Sanfilippo and Riedel; Sanfilippo and Riedel, 1973, p. 532, pl. 36, figs. 12, 13.

Centrobotrys petrushevskayae Sanfilippo and Riedel; Nigrini and Lombari, 1984, p. N 205, pl. 33, fig. 2.
Remarks: Rare in the transition between the Stichocorys wolffii Zone to Calocycletta costata Zone (late early Miocene).

\section{Cornutella profunda Ehrenberg}

Cornutella clathrata profunda Ehrenberg; Ehrenberg, 1854, p. 241.

Cornutella profunda Ehrenberg; Riedel, 1958, p. 232, pl. 3, figs. 1, 2.

Cornutella profunda Ehrenberg; Nigrini, 1967, p. 60, pl. 6, figs. 5a-c (with synonymy).

Cornutella profunda Ehrenberg; Nigrini and Lombari, 1984, p. N93, pl. 22, fig. 1.

Remarks: This Cenozoic long-range species is rare in the Leg 156 samples. Rare occurrence in early Miocene is reported in Nigrini and Lombari (1984)

\section{Cyclampterium leptetrum Sanfilippo and Riedel} (Pl. 3, Fig. 4)

Cyclampterium leptetrum Sanfilippo and Riedel; Sanfilippo and Riedel, 1970, p. 456, pl. 2, figs. 11, 12.

Cyclampterium leptetrum Sanfilippo and Riedel; Riedel and Sanfilippo, 1978, p. 67 , p. 4 , figs. $12-13$.

Cyclampterium leptetrum Sanfilippo and Riedel; Renz, 1984, p. 457, pl. 1, figs. 1-3.

Cyclampterium (?) leptetrum Sanfilippo and Riedel; Nigrini and Lombari, 1984, p. N95, pl. 22, figs. 2a, b.

Remarks: The species is frequent in all samples from the Cyrtocapsella tetrapera Zone (top of Lychnocanoma elongata Zone?) to the Calocycletta costata Zone. In general the skeletons are incomplete and comprise cephalis and thorax. Skeletons with closed abdomen are rare. Occasionally single feet protrude from the margin of the thorax without forming an abdomen. Pl. 4, fig. 13 by Riedel and Sanfilippo (1978) shows similar feet fixed at the lower margin of an open abdomen.

\section{Cyrtocapsella cornuta Haeckel}

$$
\text { (Pl. 3, Fig. 5) }
$$

Cyrtocapsa (Cyrtocapsella) cornuta Haeckel; Haeckel, 1887, p. 1513, pl. 78, fig. 9.

Cyrtocapsella cornuta Haeckel; Riedel and Sanfilippo, 1978, p. 68, pl. 4, fig. 17.

Remarks: Abundant in late early Miocene radiolarian zones of both sites.

$$
\text { Cyrtocapsella japonica (Nakaseko) }
$$

Eusyringium japonicum Nakaseko; Nakaseko, 1963, p. 193, text figs. 20-21, pl. 4 , figs. $1-3$.

Cyrtocapsella japonica (Nakaseko); Sanfilippo and Riedel, 1970, p. 452, pl. 1 , figs. 13-15 (with synonymy).

Cyrtocapsella japonica (Nakaseko); Nigrini and Lombari, 1984, p. N 107, pl. 23 , figs. $4 \mathrm{a}-\mathrm{c}$.

Remarks: Rare in the Calocycletta costata Zone of Hole 948C.

$$
\text { Cyrtocapsella tetrapera Haeckel }
$$

$$
\text { (Pl. 3, Fig. 3) }
$$

Cyrtocapsa (Cyrtocapsella) tetrapera Haeckel; Haeckel, 1887, p. 1512, pl. 78 , fig. 5

Cyrtocapsella tetrapera Haeckel; Sanfilippo and Riedel, 1970, p. 453, pl. 1, figs. 16-18 (with synonymy).

Cyrtocapsella tetrapera Haeckel; Riedel and Sanfilippo, 1978, p. 68, pl. 4, fig. 18.

Cyrtocapsella tetrapera Haeckel; Sanfilippo, Westberg-Smith and Riedel, 1985 , p. 670 , figs. $16.1 \mathrm{a}, \mathrm{b}$.

Remarks: Cyrtocapsella tetrapera Haeckel and Cyrtocapsella cornuta Haeckel mostly occur together in the late early Miocene. In the Cyrtocapsella tetrapera Zone Cyrtocapsella cornuta Haeckel is absent. Some specimens possess a fifth closed segment. Intermediate forms between Cyrtocapsella tetrapera Haeckel and C. cornuta Haeckel are frequent. 


\section{Dendrospyris bursa Sanfilippo and Riedel} (Pl. 2, Fig. 5)

Dendrospyris bursa Sanfilippo and Riedel; Sanfilippo et al., 1973, p. 217, pl. 2, figs. 9-13.

Dendrospyris bursa Sanfilippo and Riedel; Nigrini and Lombari, 1984, p. N 19, pl. 16, figs. 1a-f.

Remarks: Rare in early Miocene from the Cyrtocapsella tetrapera Zone through the Calocycletta costata Zone.

\section{Dendrospyris damaecornis (Haeckel)}

Dendrospyris damaecornis (Haeckel); Goll, 1968, p. 1420, pl. 173, figs. 1-4; text fig. 8.

Remarks: Rare in early Miocene from the Cyrtocapsella tetrapera Zone through the Calocycletta costata Zone.

\section{Didymocyrtis prismatica (Haeckel)}

(Pl. 4, Fig. 5)

Pipettella prismatica Haeckel; Haeckel, 1887, p. 305, pl. 39, fig. 6.

Didymocyrtis prismatica (Haeckel); Sanfilippo and Riedel, 1980, p. 1010, text fig. 1c.

Remarks: Rare in late early Miocene radiolarian zones. Common in the Cyrtocapsella tetrapera Zone, forming a distinct assemblage together with Calocycletta serrata Moore and Heliodiscus asteriscus Haeckel.

\section{Didymocyrtis tubaria (Haeckel)}

Pipettaria tubaria Haeckel; Haeckel, 1887, pl. 339, pl. 39, fig. 15. Cannartus tubarius (Haeckel); Riedel, 1959, p. 289, pl. 1, fig. 2.

Didymocyrtis tubaria (Haeckel); Sanfilippo and Riedel, 1980, p. 1010.

Didymocyrtis tubaria (Haeckel); Nigrini and Lombari, 1984, S 47, pl. 6, fig. 4.

Remarks: Rare in the Calocycletta costata Zone of Hole 949B.

$$
\text { Didymocyrtis violina (Haeckel) }
$$$$
\text { (Pl. 4, Fig. 6) }
$$

Cannartus violina Haeckel; Haeckel, 1887, p. 358, pl. 39, fig. 10. Cannartus violina Haeckel; Riedel, 1959, p. 290, pl. 1, fig. 3 (with synonymy). Didymocyrtis violina (Haeckel); Sanfilippo and Riedel, 1980, p. 1010.

Remarks: Generally rare in late early Miocene radiolarian zones.

$$
\text { Dorcadospyris ateuchus (Ehrenberg) }
$$

$$
\text { (Pl. 2, Fig. 3, 4) }
$$

Ceratospyris ateuchus Ehrenberg; Ehrenberg, 1873, p. 218.

Ceratospyris ateuchus Ehrenberg; Ehrenberg 1875, pl. 21, fig. 4.

Cantharospyris ateuchus (Ehrenberg); Haeckel, 1887, p. 1051.

Cantharospyris ateuchus (Ehrenberg); Riedel, 1959, p. 294, pl. 22, figs. 3, 4.

Dorcadospyris ateuchus (Ehrenberg); Riedel and Sanfilippo, 1970, pl. 15, fig. 4.

Dorcadospyris (?) or Petalospyris (?) ateuchus (Ehrenberg); Petrushevskaya and Kozlova, 1972, p. 532.

Dorcadospyris ateuchus (Ehrenberg); Riedel and Sanfilippo, 1978, p. 68, pl. 5 , fig. 3.

Remarks: Rare to common in samples from the Lychnocanoma elongata Zone and the Cyrtocapsella tetrapera Zone of Hole 948C. Questionable forms in the lower Stichocorys wolffii Zone.

\section{Dorcadospyris dentata Haeckel}

(Pl. 2, Fig. 1)

Dorcadospyris dentata Haeckel; Haeckel, 1887, p. 1040, pl. 85, fig. 6. Dorcadospyris antilope Haeckel; Haeckel, 1887, p. 1041, pl. 85, fig. 5. Dorcadospyris decussata Haeckel; Haeckel, 1887, p. 1041, pl. 85, fig. 7. Dorcadospyris dentata Haeckel; Campbell, 1954, p. D112, fig. 54.11. Dorcadospyris dentata Haeckel; Riedel, 1957, p. 79, pl. 1, fig. 4.
Dorcadospyris dentata Haeckel; Goll, 1969, p. 338, pl. 60, figs. 8, 10-13, text fig. 2.

Dorcadospyris dentata Haeckel; Riedel and Sanfilippo, 1971, p. pl. 2D, fig. $2-3$.

Dorcadospyris dentata Haeckel; Goll, 1972, p. 964, pl. 56, fig. 1-3, pl. 57, fig. 1-3.

Dorcadospyris dentata Haeckel; Holdsworth, 1975, p. 529.

Dorcadospyris dentata Haeckel; Riedel and Sanfilippo, 1978, p. 68, pl. 5, fig. 4.

Dorcadospyris dentata Haeckel; Sakai, 1980, p. 712, pl. 10, figs. 9, 10

Dorcadospyris dentata Haeckel; Nigrini and Lombari, 1984, N 29, pl. 17, fig. 2.

Dorcadospyris dentata Haeckel; Sanfilippo, Westberg-Smith and Riedel, 1985 , p. 663 , figs. $10.6 \mathrm{a}$, b.

Remarks: Dorcadospyris dentata Haeckel is present in all samples attributed to the Stichocorys wolffii Zone and to the Calocycletta costata Zone. All specimens are broken.

\section{Dorcadospyris forcipata (Haeckel)}

(Pl. 2, Fig. 2)

Dipodospyris forcipata Haeckel; Haeckel, 1887, p. 1037, pl. 85, fig. 1.

Dipodospyris forcipata Haeckel; Riedel, 1957, p. 79, pl. 1, fig. 3.

Dipodospyris forcipata Haeckel; Riedel, 1959, p. 293, pl. 1, fig. 9.

Dorcadospyris forcipata (Haeckel); Riedel and Sanfilippo, 1970, p. 523, pl. 15, fig. 7.

Dorcadospyris forcipata (Haeckel); Riedel and Sanfilippo, 1971, p. 1590, pl. 2C, figs. 20-23, pl. 3A, fig. 8.

Dorcadospyris forcipata (Haeckel); Moore, 1971, p. 740, pl. 10.

Dorcadospyris forcipata (Haeckel); Goll, 1972, p. 964, pl. 54, fig. 1-2.

Dorcadospyris forcipata (Haeckel) Group; Holdsworth, 1975, p. 529.

Dorcadospyris forcipata (Haeckel); De Wever, 1981, p. 511, pl. 3, fig. 8.

Dorcadospyris forcipata (Haeckel); Sanfilippo, Westberg-Smith and Riedel, 1985 , p. 663 , fig. $10.5 \mathrm{a}$, b.

Remarks: Dorcadospyris forcipata (Haeckel) is common in samples attributed to the Stichocorys wolffii Zone and to the Calocycletta costata Zone. It occurs with Dorcadospyris dentata Haeckel.

\section{Dorcadospyris praeforcipata Moore}

Dorcadospyris praeforcipata Moore; Moore 1971, p. 738, pl. 9, fig. 4-7.

Remarks: Rare in the Cyrtocapsella tetrapera Zone.

Eucyrtidium diaphanes Sanfilippo and Riedel

$$
\text { (Pl. 3, Fig. 2) }
$$

Eucyrtidium diaphanes Sanfilippo and Riedel; Sanfilippo et al., 1973, p. 221, pl. 5, figs. 12-14.

Eucyrtidium diaphanes Sanfilippo and Riedel; Riedel and Sanfilippo, 1978, p. 68 , pl. 5 , fig. 5 .

Remarks: This species is common in the late early Miocene.

$$
\text { Heliodiscus astericus Haeckel }
$$$$
\text { (Pl. 4, Fig. 2) }
$$

Heliodiscus astericus Haeckel; Haeckel, 1887, p. 445, pl. 33, fig. 8. Heliodiscus astericus Haeckel; Hays, 1965, p. 171, pl. 11, fig. 7. Heliodiscus astericus Haeckel; Nigrini, 1967, p. 32, pl. 3, figs. 1a, b. Heliodiscus astericus Haeckel; Nigrini and Moore, 1979, p. S73, pl. 9, figs. 1, 2. Heliodiscus astericus Haeckel; Nigrini and Lombari, 1984, p. S39, pl. 5, fig. 4.

Remarks: The species is most abundant together with Calocycletta serrata Moore in the Calocycletta tetrapera Zone.

\section{Liriospyris geniculosa Goll}

Liriospyris geniculosa Goll; Goll, 1968, p. 1427, pl. 175, figs. 21-24. Liriospyris geniculosa Goll; Nigrini and Lombari, 1984, N 47, pl. 19, fig. 3.

Remarks: This species is common in early Miocene material from the Cyrtocapsella tetrapera Zone through the Calocycletta costata Zone. 


\section{Liriospyris mutuaria Goll}

Liriospyris mutuaria Goll; Goll, 1968, p. 1428, figs. 6, 10, 11, 14; text fig. 9. Liriospyris mutuaria Goll; De Wever, 1981, p. 511, pl. 2, fig. 1.

Remarks: This species is common in early Miocene material from the Cyrtocapsella tetrapera Zone through the Calocycletta costata Zone.

\section{Liriospyris parkerae Riedel and Sanfilippo}

Liriospyris parkerae Riedel and Sanfilippo; Riedel and Sanfilippo, 1971, p. 1590, pl. 2C, fig. 15, pl. 5, fig. 4.

Liriospyris parkerae Riedel and Sanfilippo; De Wever, 1981, p. 511, pl. 1, fig. 11.

Remarks: This species is common in the Calocycletta costata Zone and in the transition between the Calocycletta costata Zone and the Stichocorys wolffii Zone.

\section{Liriospyris stauropora (Haeckel)}

\section{(Pl. 2, Fig. 7)}

Trissocyclus stauropora Haeckel; Haeckel, 1887, p. 987, pl. 83, fig. 5.

Liriospyris stauropora (Haeckel); Goll, 1968, p. 1431, pl. 175, figs. 1-3, 7, text fig. 9.

Liriospyris stauropora (Haeckel); Riedel and Sanfilippo, 1971, p. 1590, pl. 2C, figs. 16-19.

Liriospyris stauropora (Haeckel); De Wever, 1981, p. 511, pl. 1, figs. 12-13.

Liriospyris stauropora (Haeckel); Nigrini and Lombari, 1984, N 51, pl. 19, fig. 5.

Remarks: Common to abundant in the late early Miocene sections of both sites.

\section{Lithochytris vespertilio Ehrenberg}

Lithochytris vespertilio Ehrenberg; Ehrenberg, 1873, p. 239, no. 148. Lithochytris vespertilio Ehrenberg; Ehrenberg, 1875, p. 76, pl. 4, fig. 10 Lithochytris vespertilio Ehrenberg; Bütschli, 1882, p. 532, pl. 31, fig. 4. Lithochytris vespertilio Ehrenberg; Haeckel, 1887, p. 1365.

Lithochytris vespertilio Ehrenberg; Riedel and Sanfilippo, 1970, pl. 9, fig. 8,9.

Lithochytris vespertilio Ehrenberg; Moore, 1971, p. 741, pl. 1, fig. 4

Lithochytris vespertilio Ehrenberg; Nigrini, 1974, pl. 1G, figs. 4-6.

Lithochytris vespertilio Ehrenberg; Ling, 1975, p. 726, pl. 10, figs. 1-3.

Lithochytris vespertilio Ehrenberg; Kling, 1978, p. 234, fig. 14.

Remarks: This is an Eocene species reworked in Sample 156-948C-11X$2,16-19 \mathrm{~cm}$. The normal fauna is assigned to the Cyrtocapsella tetrapera Zone.

\section{Lychnocanoma elongata (Vinassa)}

(Pl. 4, Fig. 4)

Tetrahedrina elongata Vinassa de Regny; Vinassa de Regny, 1900, p. 243, pl. 2, fig. 31.

Lychnocanoma elongata (Vinassa); Riedel and Sanfilippo, 1978, p. 70, pl. 7, fig. 4.

Remarks: Rare throughout the cores.

\section{Lychnocanoma sp.}

Theoperid gen. et sp. indet.; Sanfilippo, Westberg-Smith and Riedel, 1985, figs. 19, 4-6.

Remarks: Lychnocanoma possessing three feet. Occurs with Lychnocanoma elongata Vinassa de Regny.

\section{Orodapis spongiosa Friend and Riedel}

Orodapis spongiosa Friend and Riedel; Friend and Riedel, 1967, p. 222, pl. 1, fig. $7-10$.

Remarks: This orospherid species constitutes the largest intact radiolarian tests recovered from the Leg 156 sediments. Well-preserved skeletons oc- cur in Core 949B-19X and have diameters greater than $2 \mathrm{~mm}$. These radiolarians represent the "fat rads" in the recrystallized zone of Hole 948C. Orodapis spinosa Friend and Riedel is known from early Oligocene to early early Miocene (Friend and Riedel, 1967). According to the occurrence in the transition Stichocorys wolffii Zone to Calocycletta costata Zone in Core $949 \mathrm{~B}-19 \mathrm{X}$, this species possibly has a longer range and is also common in the late early Miocene.

\section{Oroscena carolae Friend and Riedel}

$$
\text { (P1. 4, Fig. 1) }
$$

Oroscena carolae Friend and Riedel; Friend and Riedel, 1967, p. 225, pl. 2, figs. $9-10$, pl. 3, figs. $1-2$

Remarks: This large radiolarian species has more fragile skeletons as Orodapis spongiosa Friend and Riedel. It is common but complete tests are rare. They occur with Orodapis spongiosa Friend and Riedel in Core 949B$19 X$.

$$
\text { Orospherids gen. indet. }
$$

Remains of orospherids are present in almost all samples of Leg 156 . Because these delicate forms are usually fragmented they cannot be exactly determined. The remains are similar to species of the genera Oroscena Haeckel (1887) and Orodapis Friend and Riedel (1967). Because of intense recrystallization and transformation of the biogenic opal to quartz the orospherids become diagenetically more "stable". These radiolarians are embedded as spongy spherical bodies in the soft claystones of the décollement zone with diameters up to $2 \mathrm{~mm}$.

\section{Siphostichoartus praecorona Nigrini}

Siphostichoartus praecorona Nigrini; Nigrini, 1977, p. 528, pl. 2, figs. 8-9. Siphostichoartus praecorona Nigrini; De Wever, 1981, p. 512, pl. 4, fig. 4.

Remarks: Extremely rare. Occurs in Sample 156-949B-19X-1, 141-145 $\mathrm{cm}$, of the transition Stichocorys wolffii Zone to Calocycletta costata Zone.

$$
\text { Siphostichoartus corona (Haeckel) }
$$

Cryptophormis (Acanthocyrtis) corona Haeckel; Haeckel, 1887, p. 1462, pl. 77 , fig. 15.

Siphostichoartus corona (Haeckel); Nigrini, 1977, p. 257, pl. 2, figs. 5-7.

Phormostichoartus corona (Haeckel); Riedel and Sanfilippo, 1978, p. 71, pl. 7 , fig. 12.

Siphostichoartus corona (Haeckel); De Wever, 1981, p. 512, pl. 4, fig. 3.

Remarks: Rare in all radiolarian zones.

\section{Stichocorys delmontensis (Campbell and Clark)}

Eucyrtidium delmontense Campbell and Clark; Campbell and Clark, 1944, p. 56, pl. 7, figs. 19, 20.

Stichocorys delmontensis (Campbell and Clark); Riedel and Sanfilippo, 1978, p. 74, pl. 9, fig. 10.

Stichocorys delmontensis (Campbell and Clark); Nigrini and Lombari, 1984, p. N 129, pl. 25, fig. 4.

Stichocorys delmontensis (Campbell and Clark); Sanfilippo, Westberg-Smith and Riedel, 1985, p. 681, figs 23.1a, b.

Remarks: Stichocorys delmontensis (Campbell and Clark) is rare in the Leg 156 cores. The species is part of the radiolarian assemblage of the Calocycletta costata Zone. Why it is not detected in the upper décollement samples is a problem. A possible reason is the similarity to Stichocorys wolffii (Haeckel) and the fragmentation of the Stichocorys tests in this interval. Stichocorys wolffii tests seem to be more stable against mechanical breaking than $S$. delmontensis tests.

\section{Stichocorys wolffii (Haeckel)}

(P1. 3, Fig. 1)

Stichocorys wolffii Haeckel; Haeckel, 1887, p. 1479, pl. 80, fig. 10.

Stichocorys wolffii Haeckel; Riedel and Sanfilippo, 1971, pl. 2E, figs. 8, 9.

Stichocorys wolffii Haeckel; Riedel and Sanfilippo, 1978, pl. 1, fig. 3, pl. 9, fig. 12 . 
Stichocorys wolffii Haeckel, Nigrini and Lombari, 1984, p. N 135, pl. 25, fig. 7 (with synonymy).

Stichocorys wolffii Haeckel; Sanfilippo, Westberg-Smith and Riedel, 1985, p. 682 , figs $23.3 \mathrm{a}, \mathrm{b}$.

Remarks: Complete specimens are rare. Proximal parts comprising cephalis, thorax and abdomen are more common.

\section{Stylatractus universus Hays Group}

Stylatractus universus Hays; Hays, 1970, p. 215, pl. 1 figs. 1, 2. Stylatractus universus Hays; Nigrini and Lombari, 1984, p. 215, pl. 1, figs. 1, 2.

Remarks: According to the discussion in Nigrini and Lombari (1984), Stylatractus universus Hays is seen to be conspecific with Axoprunum angelinum (Campbell and Clark). The morphotype occurs throughout the radiolarian-bearing sediments of the décollement with medium frequency. No biostratigraphically significant tendency in vertical distribution is obvious.

\section{Stylodictya aculeata Jørgensen}

Stylodictya aculeata Jørgensen; Jørgensen,1905, p. 119, pl. 10, fig. 41. Stylodictya aculeata Jørgensen; Petrushevskaya, 1967, p. 35, pl. 17, figs. 1-3. Stylodictya aculeata Jørgensen; Nigrini and Moore, 1979, p. S 101, pl. 13, figs. 3,4 .

Stylodictya aculeata Jørgensen; Nigrini and Lombari, 1984, p. S 69, pl. 10, figs. 1a, b.

Remarks: Relatively rare in the late early Miocene close to the Calocycletta costata Zone.

Tholospyris anthophora (Haeckel)

(Pl. 2, Fig. 6)

Dictyospyris anthophora Haeckel; Haeckel, 1887, p. 1076, pl. 89, fig. 8.

? Dictyospyris distoma Haeckel; Haeckel, 1887, p. 1073, pl. 89, figs. 11, 12.

Tholospyris anthophora (Haeckel); Goll, 1969, p. 324, pl. 55, figs. 1-4, text fig. 1.

Tholospyris anthophora (Haeckel); Nigrini and Lombari, 1984, N69, pl. 20, fig. 1.

Remarks: Tholospyris anthophora (Haeckel) is the most common spyrid in the Leg 156 samples.

\section{Tholospyris kantiana (Haeckel)}

(Pl. 2, Fig. 8)

Tricolospyris kantiana Haeckel; Haeckel, 1887, p. 1098, pl. 88, fig. 10.

Tholospyris kantiana (Haeckel); Goll, 1969, p. 327, pl. 58, figs. 17-19, 23; text fig. 1.

Tholospyris kantiana (Haeckel); De Wever 1981, p. 512, pl. 2, fig. 6.

Tholospyris kantiana (Haeckel); Nigrini and Lombari, 1984, p. N 71, pl. 20, figs. $2 \mathrm{a}-\mathrm{c}$.

Remarks: This species is very difficult to determine from the literature. The skeletons found in the Leg 156 represent the central parts of T. kantiana (Haeckel) including the sagittal ring and the lattice shell. The lattice extensions documented by Goll (1969) were not observed. In the cores the species is present in the late early Miocene radiolarian zones.

\section{Tholospyris mammillaris (Haeckel)}

$$
\text { (Pl. 2, Fig. 10) }
$$

Dictyospyris mammillaris Haeckel; Haeckel, 1887, p. 1076, pl. 89, figs. 9, 10. Tholospyris mammillaris (Haeckel); Goll, 1969, p. 327, pl. 55, figs. 5, 6; text fig. 1.

Tholospyris mammillaris (Haeckel); De Wever, 1981, p. 512, pl. 1, fig. 6. Tholospyris mammillaris (Haeckel); Nigrini and Lombari, 1984, p. N 73, pl. 20, figs. 3a, b.

Remarks: This species is one of the most abundant spyrids in the Leg 156 samples. Except for the Lychnocanoma elongata Zone Tholospyris mammillaris (Haeckel) occurs in all radiolarian zones of the early Miocene.
Tympanidium binoctonum Haeckel

(Pl. 2, Fig. 9)

Tympanidium binoctonum Haeckel; Haeckel, 1887, p. 1004, pl. 94, fig. 18. Tympanomma binoctonum (Haeckel); Petrushevskaya and Kozlova, 1972, p. 533 , pl 39, figs. 23,24 .

Tympanidium binoctonum Haeckel; Nigrini and Lombari, 1984, p. N 77, pl. 20, fig. 4.

Remarks: In Leg 156 cores, Tympanidium binoctonum Haeckel is abundant starting from the base of the Cyrtocapsella tetrapera Zone through the Calocycletta costata Zone.

\section{Zygocircus productus (Hertwig)}

Lithocircus productus Hertwig; Hertwig, 1879, p. 69, pl. 7, fig. 4.

Zygocircus productus (Hertwig); Haeckel, 1887, p. 948.

Zygocircus productus (Hertwig) tricarinatus Goll; Goll 1979, p. 380, pl. 1, figs. 1-2, 5-15 (with synonymy).

Zygocircus productus (Hertwig) tricarinatus Goll; Nigrini and Lombari, 1984, p. N3, pl. 15, figs. 2 a, b.

Remarks: Morphotypes of Zygocircus productus (Hertwig) are abundant in all well preserved and slightly recrystallized samples. Most of them can be determined as the subspecies tricarinatus described by Goll (1979).

Nigrini and Lombari note that this subspecies is most frequent in late early and early middle Miocene.

\section{ACKNOWLEDGMENTS}

I would like to thank our co-chief scientists and all the people from the JOIDES Resolution for their kindness providing an outstandingly friendly atmosphere during the entire cruise. In addition, I am very grateful to ODP and the German Science Foundation for giving funds for the project. Very special thanks to Prof. Dr. E. Flügel (University of Erlangen, Germany) for supporting this research.

\section{REFERENCES}

Bader, R.G., Gerard, R.D., et al., 1970. Init. Repts. DSDP, 4: Washington (U.S. Govt. Printing Office).

Biju-Duval, B., Moore, J.C., et al., 1984. Init. Repts. DSDP, 78A: Washington (U.S. Govt. Printing Office).

Bütschli, O., 1882. Beiträge zur Kenntnis der Radiolarienskelette, insbesondere der Cyrtida. Z. Wiss. Zool., 36:485-540.

Campbell, A.S., 1954. Radiolaria. In Moore, R.C. (Ed.), Treatise on Invertebrate Paleontology, Part D, Protista 3. Geol. Soc. Am. and Univ. of Kansas Press, D:11-195.

Campbell, A.S., and Clark, B.L., 1944. Miocene radiolarian faunas from Southern California. Spec. Pap.-Geol. Soc. Am., 51:1-76.

De Wever, P., 1981. Spyrids, artostrobiids, and Cretaceous radiolarians from the western Pacific, Deep Sea Drilling Project Leg 61. In Larson, R.L., and Schlanger, S.O., et al., Init. Repts. DSDP, 61: Washington (U.S. Govt. Printing Office), 507-520.

Ehrenberg, C.G., 1854. Mikrogeologie: Das Erden und Felsen schaffende Wirken des unsichtbar kleines selbständigen Lebens auf der Erde: Leipzig (Leopold Voss).

, 1873. Grössere Felsproben des Polycystinen-Mergels von Barbados mit weiteren Erläuterungen. K. Preuss. Akad. Wiss. Berlin, Monatsberichte, Jahre 1873:213-263.

, 1875. Fortsetzung der mikrogeologischen Studien als GesammtUebersicht der mikroskopischen Paläontologie gleichartig analysirter Gebirgsarten der Erde, mit specieller Rücksicht auf den PolycystinenMergel von Barbados. Abh. K. Akad. Wiss. Berlin, Jahre 1875:1-225.

Friend, J.K., and Riedel, W.R., 1967. Cenozoic Orosphaerid radiolarians from tropical Pacific sediments. Micropaleontology, 3:217-232.

Goll, R.M., 1968. Classification and phylogeny of Cenozoic Trissocyclidae (Radiolaria) in the Pacific and Caribbean basins, Part I. J. Paleontol., 42:1409-1432.

, 1969. Classification and phylogeny of Cenozoic Trissocyclidae (Radiolaria) in the Pacific and Caribbean basins, Part II. J. Paleontol., 43:322-339. 
1972. Systematics of eight Tholospyris taxa (Trissocyclidae, Radiolaria). Micropaleontology, 18:443-475.

1979. The Neogene evolution of Zygocircus, Neosemantis and Callimitra: their bearing on nassellarian classification-a revision of the Palgiacanthoidea. Micropaleontology, 25:365-396.

Haeckel, E., 1887. Report on the Radiolaria collected by H.M.S. Challenger during the years 1873-1876. Rep. Sci. Results Voy. H.M.S. Challenger, 1873-1876, Zool., 18:1-1803.

Hays, J.D., 1965. Radiolaria and late Tertiary and Quaternary history of Antarctic seas. In Llano, G.A. (Ed.), Biology of the Antarctic Seas II. Antarct. Res. Ser., 5:125-184.

, 1970. Stratigraphy and evolutionary trends of radiolaria in North Pacific deep sea sediments. In Hays, J.D. (Ed.), Geological Investigations of the North Pacific. Mem.-Geol. Soc. Am., 126:185-218.

Hertwig, R., 1879. Der Organismus der Radiolarien: Jena (Fischer).

Holdsworth, B.K., 1975. Cenozoic radiolaria biostratigraphy: Leg 30: tropical and equatorial Pacific. In Andrews, J.E., Packham, G., et al., Init. Repts. DSDP, 30: Washington (U.S. Govt. Printing Office), 499-537.

Jørgensen, E., 1905. The protist plankton and the diatoms in bottom samples. Bergens Mus. Skr., 49-151, 195-225.

Kling, S.A., 1978. Radiolaria. In Haq, B.H., and Boersma, A. (Eds.), Introduction to Marine Micropaleontology: Amsterdam (Elsevier).

Ling, H.Y., 1975. Radiolaria: Leg 31 of the Deep Sea Drilling Project. In Karig, D.E., Ingle, J.C., Jr., et al., Init. Repts. DSDP, 31: Washington (U.S. Govt. Printing Office), 703-761.

Mascle, A., Moore, J.C., et al., 1988. Proc. ODP, Init. Repts., 110: College Station, TX (Ocean Drilling Program).

Moore, T., 1971. Radiolaria. In Tracey, J.I., Jr., Sutton, G.H., et al., Init. Repts. DSDP, 8: Washington (U.S. Govt. Printing Office), 727-775.

Moore, T.C., 1972. Mid-Tertiary evolution of the radiolarian genus Calocycletta. Micropaleontology, 18:144-152.

Nakaseko, K., 1963. Neogene Cyrtoidea (Radiolaria) from the Isozaki Formation in Ibaraki Prefecture, Japan. Sci. Rep., Coll. Gen. Educ., Osaka Univ., 12:165-198.

Nigrini, C., 1967. Radiolaria in pelagic sediments from the Indian and Atlantic Oceans. Bull. Scripps Inst. Oceanogr., 11:1-125.

, 1974. Cenozoic Radiolaria from the Arabian Sea, DSDP Leg 23. In Davies, T.A., Luyendyk, B.P., et al., Init. Repts. DSDP, 26: Washington (U.S. Govt. Printing Office), 1051-1121.

1977. Tropical Cenozoic Artostrobiidae (Radiolaria). Micropaleontology, 23:241-269.

Nigrini, C., and Lombari, G., 1984. A Guide to Miocene Radiolaria. Spec. Publ. Cushman Found. Foraminiferal Res., 22.

Nigrini, C., and Moore, T.C., 1979. A Guide to Modern Radiolaria. Spec. Publ. Cushman Found. Foraminiferal Res., 16.

Nigrini, C., and Sanfilippo, A., in press. Cenozoic radiolarian stratigraphy for low and middle latitudes. ODP Tech. Note, 26.

Petrushevskaya, M.G., 1967. Radiolyarii otryadov Spumellaria i Nassellaria antarkticheskoi oblasti (Antarctic Spumelline and Nasselline radiolarians). In Resultaty Biologicheskikh Issledovanii Sovetskoi Antarkticheskoi Ekspeditsii 1955-1958 (Vol. 3): Issled. Fauny Morei, Zool. Inst. Akad. Nauk SSSR, 4:1-186.

Petrushevskaya, M.G., and Kozlova, G.E., 1972. Radiolaria, Leg 14, Deep Sea Drilling Project. In Hayes, D.E., Pimm, A.C., et al., Init. Repts. DSDP, 14: Washington (U.S. Govt. Printing Office), 495-648.

Renz, G.W., 1984. Cenozoic radiolarians from the Barbados Ridge, Lesser Antilles Subduction Complex, Deep Sea Drilling Project Leg 78A. In
Biju-Duval, B., Moore, J.C., et al. Init. Repts. DSDP, 78A: Washington (U.S. Government Printing Office), 447-462.

Riedel, W.R., 1957. Radiolaria: a preliminary stratigraphy. In Petterson, H. (Ed.), Rep. Swed. Deep-Sea Exped., 1947-1948 (Vol. 6): Goteborg (Elanders Boktryckeri Aktiebolag), 59-96.

, 1958. Radiolaria in Antarctic sediments. Rep. B.A.N.Z. Antarct. Res. Exped., Ser. B, 6:217-255.

, 1959. Oligocene and Lower Miocene Radiolaria in tropical Pacific sediments. Micropaleontology, 5:285-302.

Riedel, W.R., and Sanfilippo, A., 1970. Radiolaria, Leg 4, Deep Sea Drilling Project. In Bader, R.G., Gerard, R.D., et al., Init. Repts. DSDP, 4: Washington (U.S. Govt. Printing Office), 503-575.

, 1971. Cenozoic Radiolaria from the western tropical Pacific, Leg

7. In Winterer, E.L., Riedel, W.R., et al., Init. Repts. DSDP, 7 (Pt. 2): Washington (U.S. Govt. Printing Office), 1529-1672.

, 1973. Cenozoic Radiolaria from the Caribbean, Deep Sea Drilling Project, Leg 15. In Edgar, N.T., Saunders, J.B., et al., Init. Repts. DSDP, 15: Washington (U.S. Govt. Printing Office), 705-751.

, 1978. Stratigraphy and evolution of tropical Cenozoic radiolarians. Micropaleontology, 24:61-96.

Sakai, T., 1980. Radiolarians from Sites 434, 435, and 436, Northwest Pacific, Leg 56, Deep Sea Drilling Project. In von Huene, R., Nasu, N., et al., Init. Repts. DSDP, 56, 57 (Pt. 2): Washington (U.S. Govt. Printing Office), 695-733.

Sanfilippo, A., Burckle, L.H., Martini, E., and Riedel, W.R., 1973. Radiolarians, diatoms, silicoflagellates and calcareous nannofossils in the Mediterranean Neogene. Micropaleontology, 19:209-234.

Sanfilippo, A., and Riedel, W.R., 1970. Post-Eocene "closed" theoperid radiolarians. Micropaleontology, 16:446-462.

, 1973. Cenozoic Radiolaria (exclusive of theoperids, artostrobiids and amphipyndacids) from the Gulf of Mexico, Deep Sea Drilling Project Leg 10. In Worzel, J.L., Bryant, W., et al., Init. Repts. DSDP, 10: Washington (U.S. Govt. Printing Office), 475-611.

, 1980. A revised generic and suprageneric classification of the Artiscins (Radiolaria). J. Paleontol., 54:1008-1011.

Sanfilippo, A., Westberg-Smith, M.J., and Riedel, W.R., 1985. Cenozoic radiolaria. In Bolli, H.M., Saunders, J.B., and Perch-Nielsen, K. (Eds.), Plankton Stratigraphy: Cambridge (Cambridge Univ. Press), 631-712.

Shipboard Scientific Party, 1995. Site 948. In Shipley, T.H., Ogawa, Y., Blum, P., et al., Proc. ODP, Init. Repts., 156: College Station, TX (Ocean Drilling Program), 87-192.

Shipley, T.H., Ogawa, Y., Blum, P., et al., 1995. Proc. ODP, Init. Repts., 156: College Station, TX (Ocean Drilling Program).

Steiger, T., Ogawa, Y., and Kastner, M., in press. Radiolarian recrystallization and selective diagenesis in the décollement zone of the Northern Barbados Active Margin (Lesser Antilles Arc). Facies.

Theyer, F., Mato, C.Y., and Hammond, S.R., 1978. Paleomagnetic and geochronologic calibration of latest Oligocene to Pliocene radiolarian events, equatorial Pacific. Mar. Micropaleontol., 3:377-395.

Vinassa de Regny, P.E., 1900. Radiolari Miocenici Italiani. Mem. R. Acad. Sci. Inst. Bologna, Ser. 5, 8:227-257.

Date of initial receipt: 12 February 1996

Date of acceptance: 21 July 1996

Ms 156SR-006 


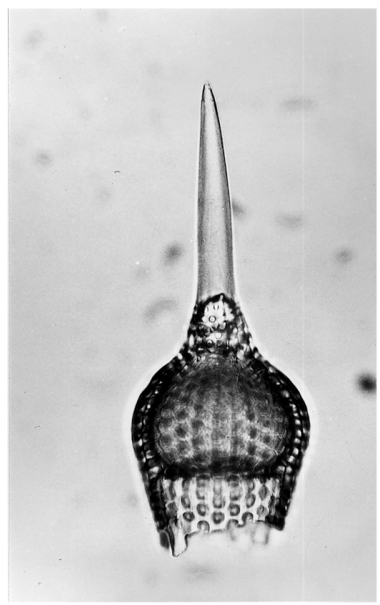

1

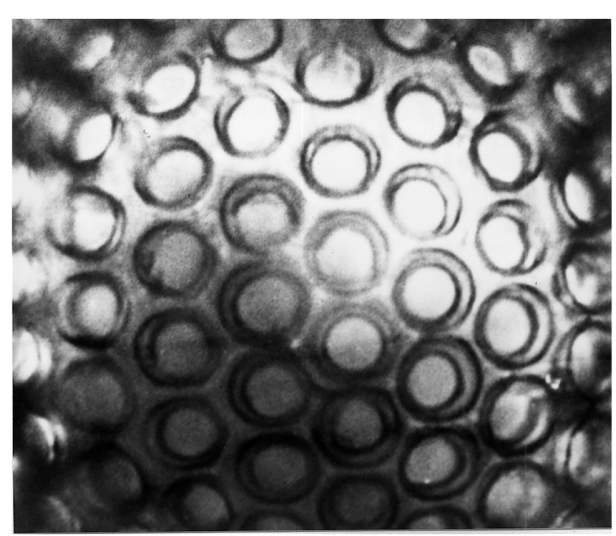

4

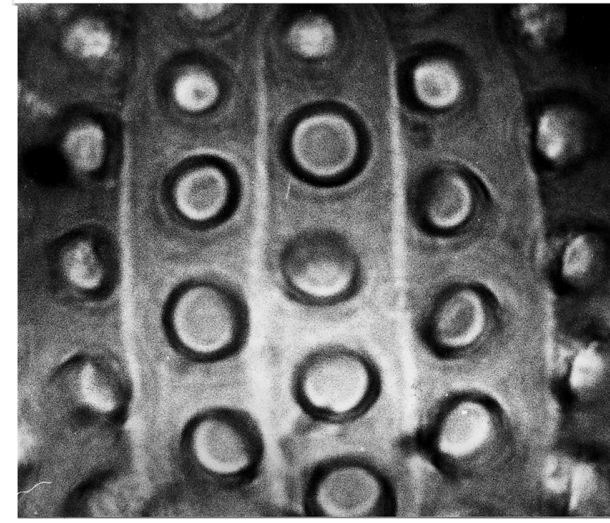

2

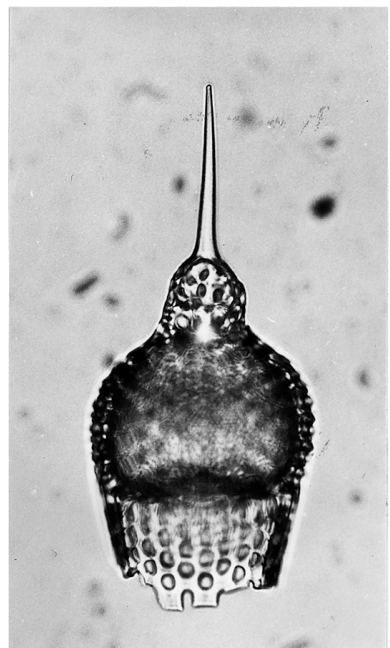

3

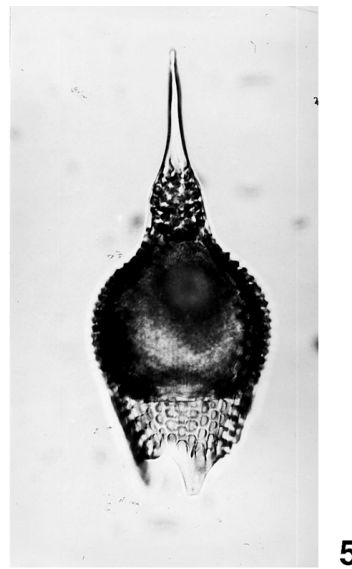

5

6

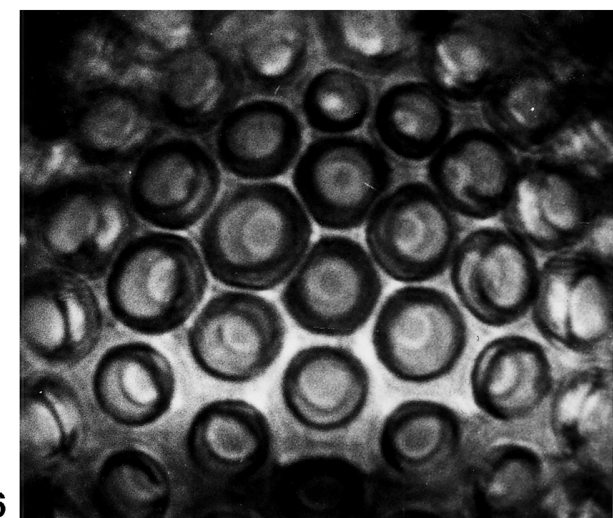

Plate 1. 1. Calocycletta costata (Riedel), Sample 156-948C-10X-CC; 165×. 2. Calocycletta costata (Riedel), detail of abdominal surface, Sample 156-948C10X-CC; 1315×. 3. Calocycletta virginis Haeckel, Sample 156-948C-11X-1, 146-150 cm; 165×. 4. Calocycletta virginis Haeckel, details of abdominal surface, Sample 156-984C-11XZ-1, 146-150 cm; 1315×. 5. Calocycletta serrata Moore, sample 156-948C-11X-2, 63-67 cm; $165 \times$. 6. Calocycletta serrata Moore, details of abdominal surface, Sample 156-948C-11X-2, 63-67 cm; 1315×. 


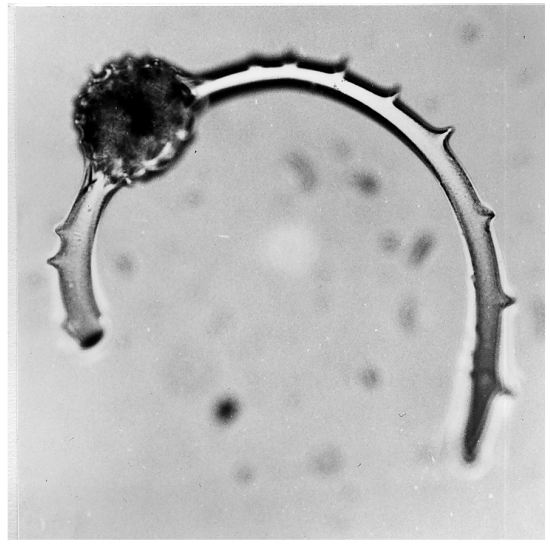

1
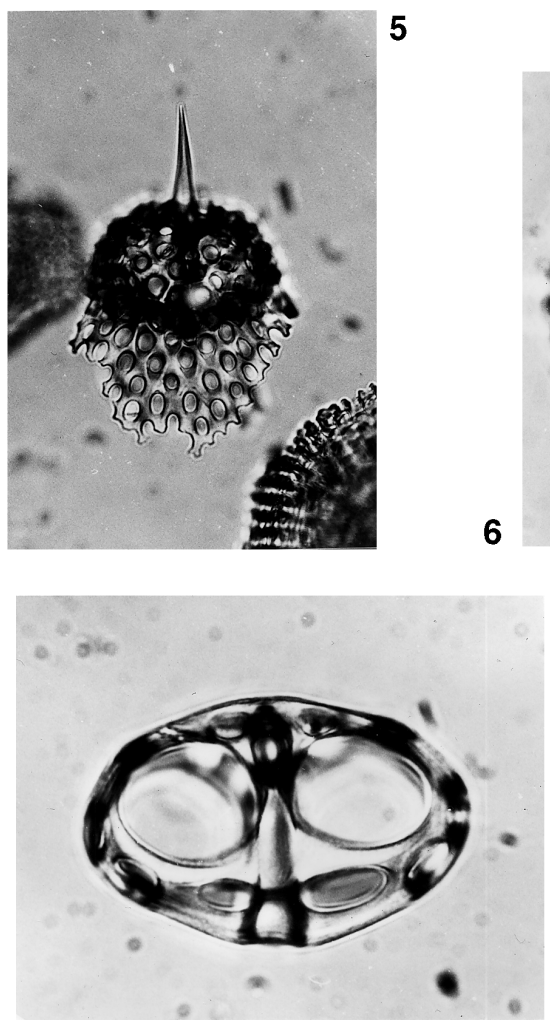

\section{7}

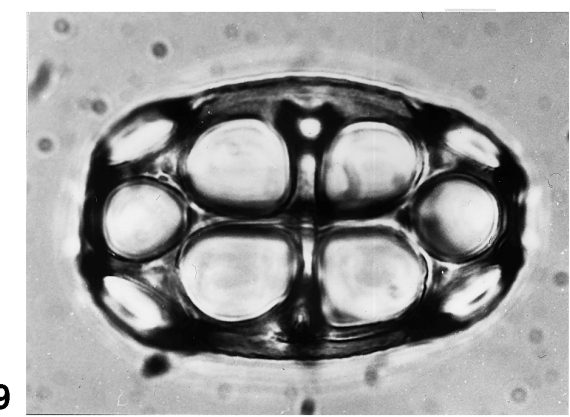

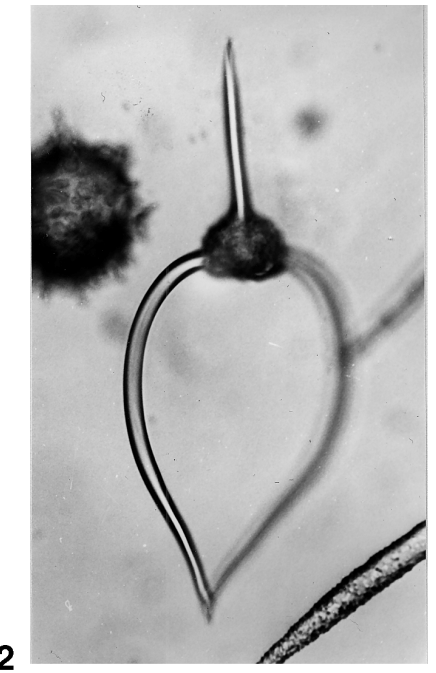

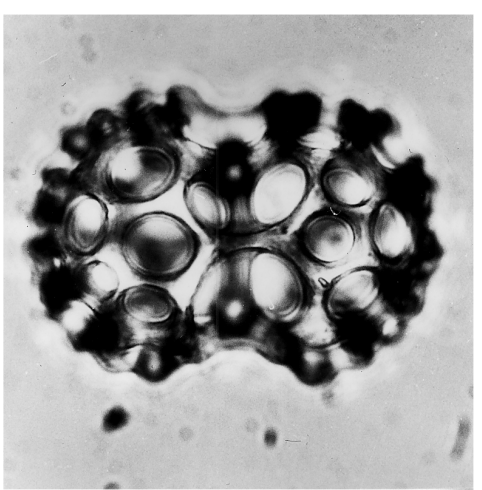

3
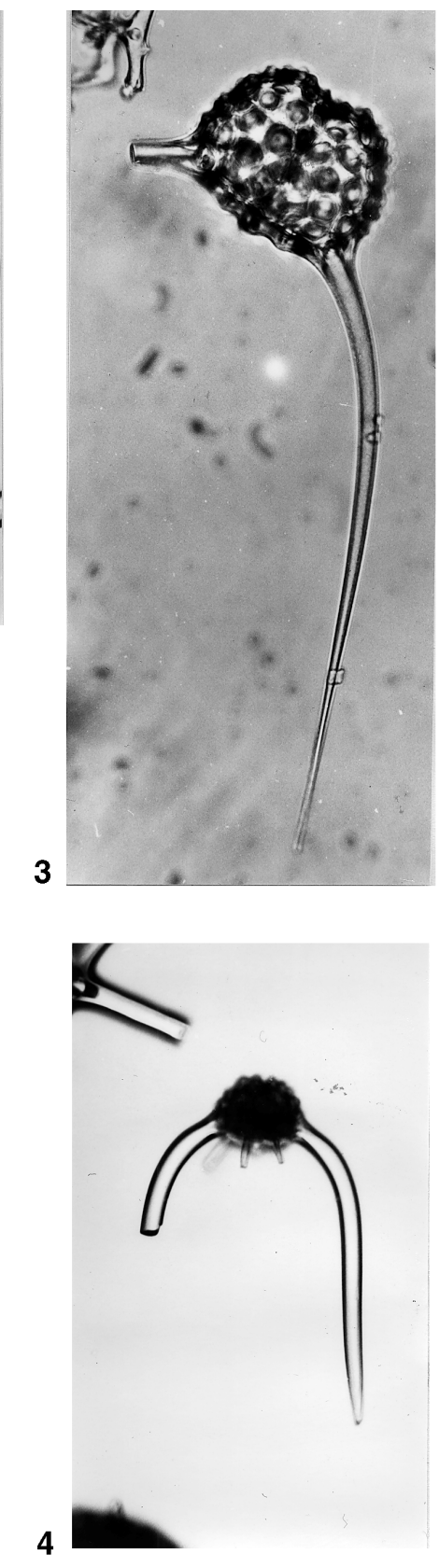

4

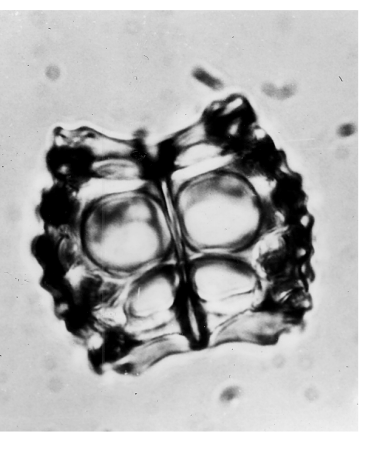

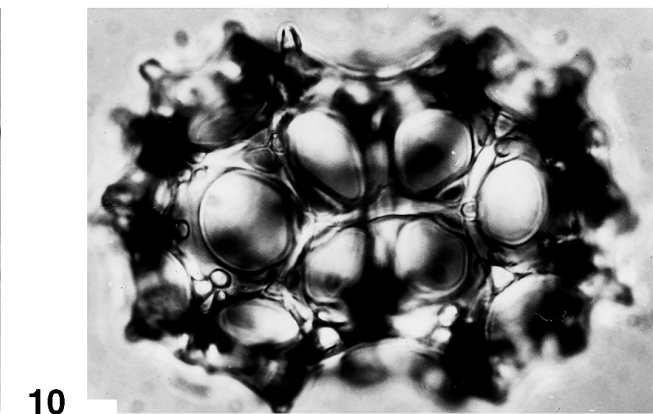

Plate 2. 1. Dorcadospyris dentata Haeckel, Sample 156-948C-10X-4, 52-56 cm; 145×. 2. Dorcadospyris forcipata (Haeckel), Sample 156-949B19X-4, 68 cm; 90×. 3. Dorcadospyris ateuchus (Ehrenberg), Sample 156-948C-11X-2, 101-103 cm; 250×. 4. Dorcadospyris ateuchus (Ehrenberg), Sample 156-949B-19X-3, 138-140 cm; 100×. 5. Dendrospyris bursa Sanfilippo and Riedel, Sample 156-949B-19X-2, 13-17 cm; 205×. 6. Tholosypris anthophora (Haeckel), Sample 156-949B-19X-CC; 300×. 7. Liriospyris stauropora (Haeckel), Sample 156-949B-19X-CC; 260×. 8. Tholosypris kantiana (Haeckel), Sample 156-949B-10XCC; 200×. 9. Tympanidium binoctonum Haeckel, Sample 156-949V-19X-CC; 330×. 10. Tholospyris mammillaris (Haeckel), Sample 156-949B-19X-CC; 410X. 


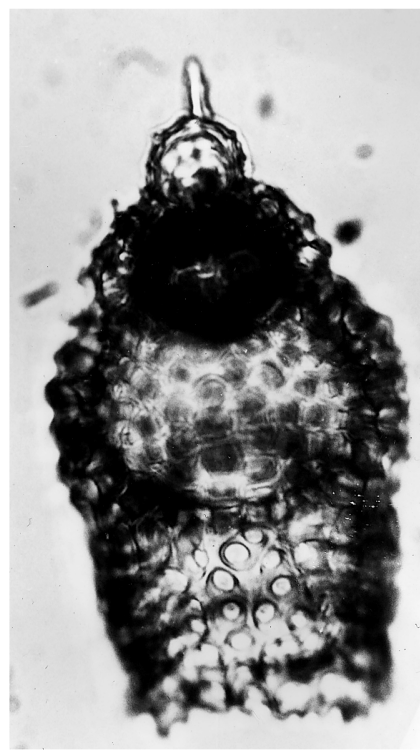

1

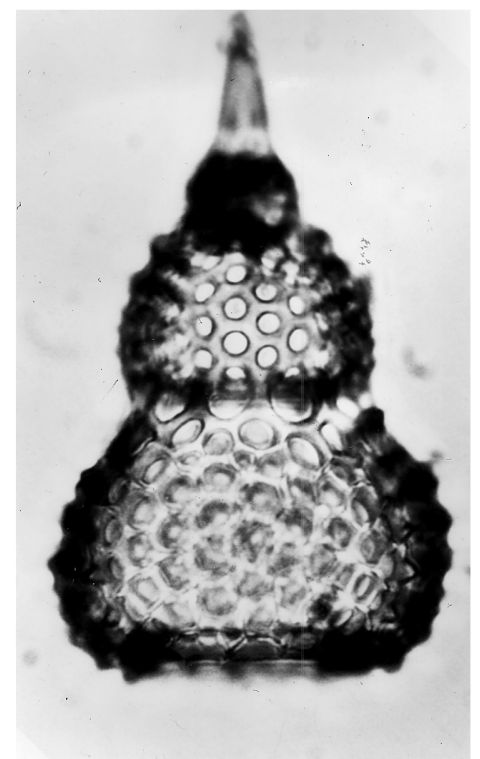

2

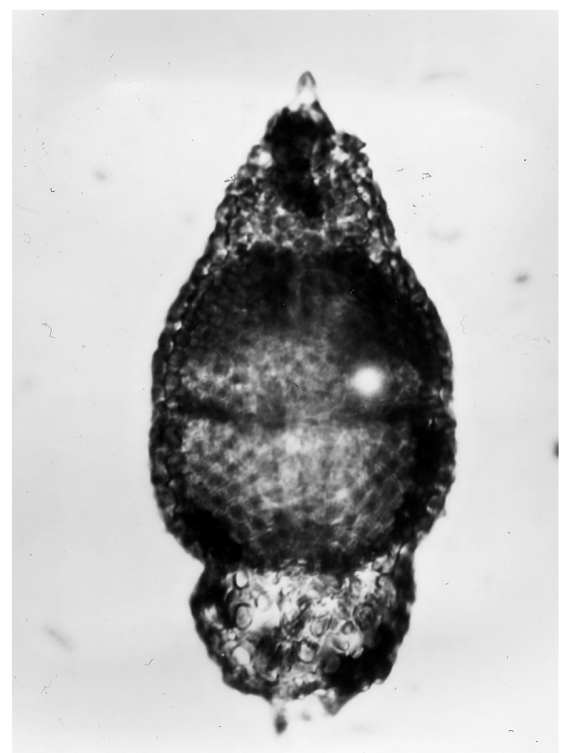

3
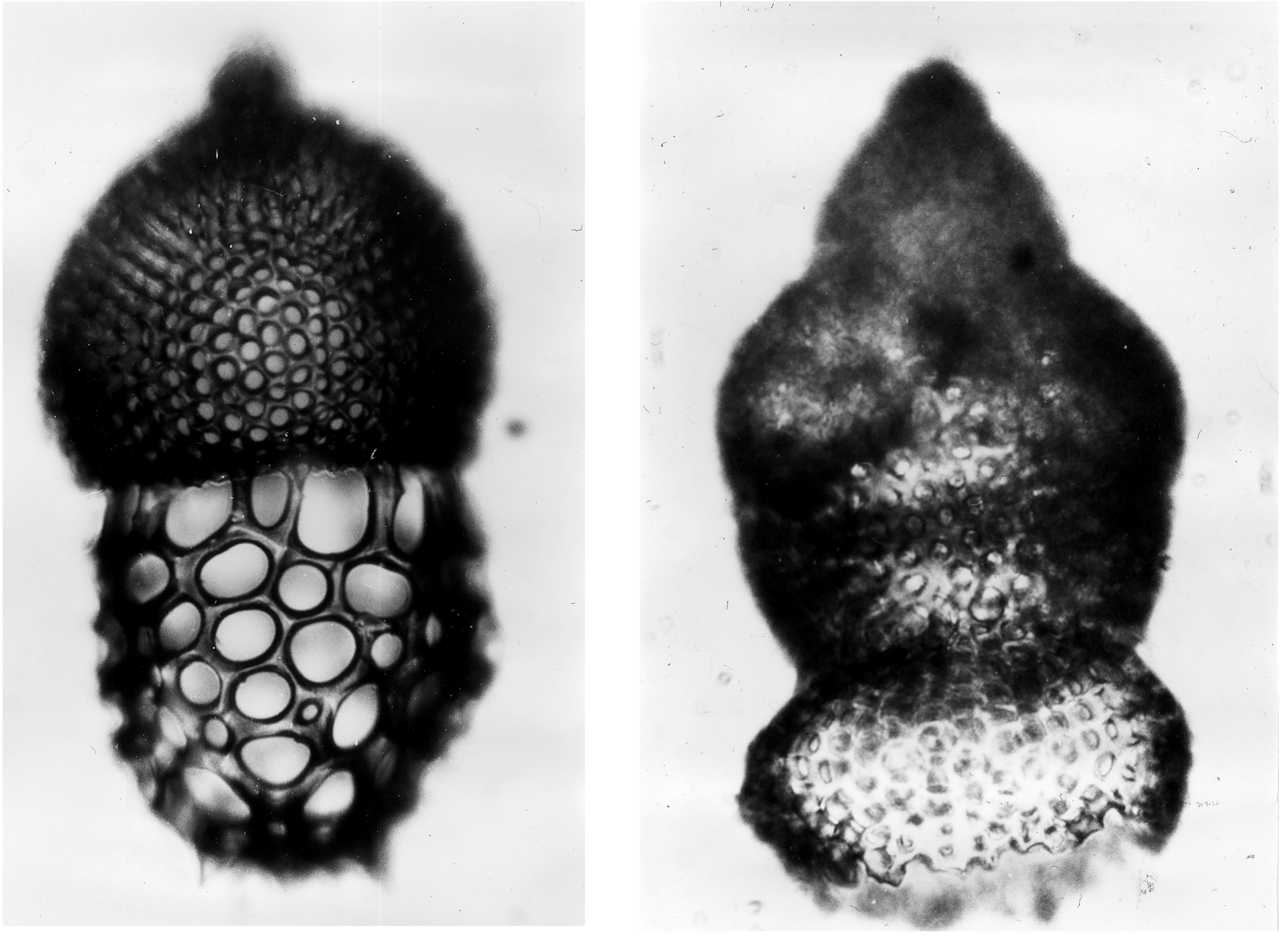

4

5

Plate 3. 1. Stichocorys wolffii (Haeckel), Sample 156-949B-19X-4, 6-8 cm; 410×. 2. Eucyrtidium diaphanes Sanfilippo and Riedel, Sample 156-948C-10X-5, 45-47 cm; 410×. 3. Cyrtocapsella tetrapera Haeckel, Sample 156-938C-11X-2, 16-19 cm; 250X. 4. Cyclampterium leptetrum Sanfilippo and Riedel, Sample 156-949B-19X-CC; 165×. 5. Cyrtocapsella cornuta Haeckel, Sample 156-948-11X-2, 16-19 cm; 410×. 

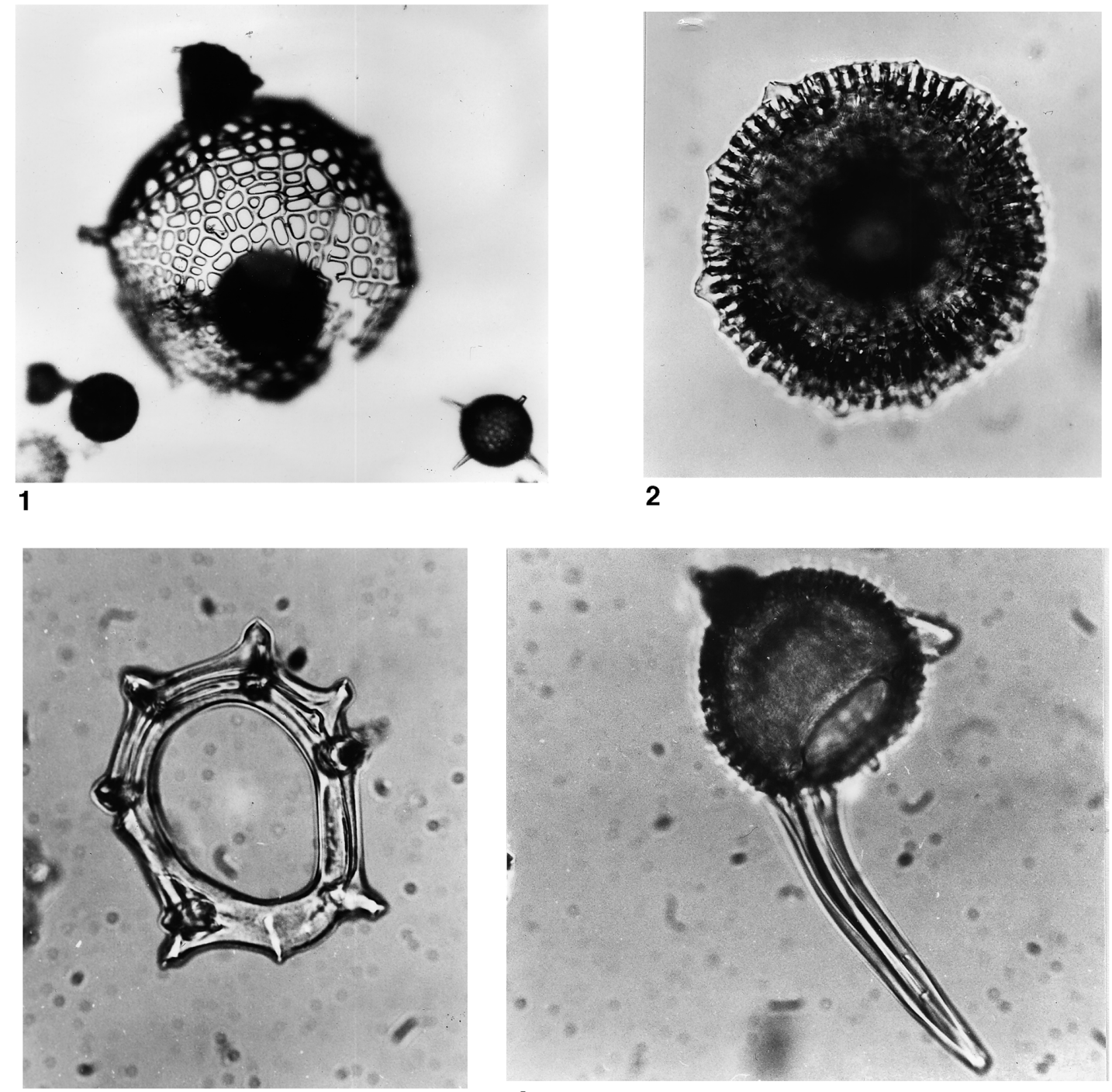

3

4
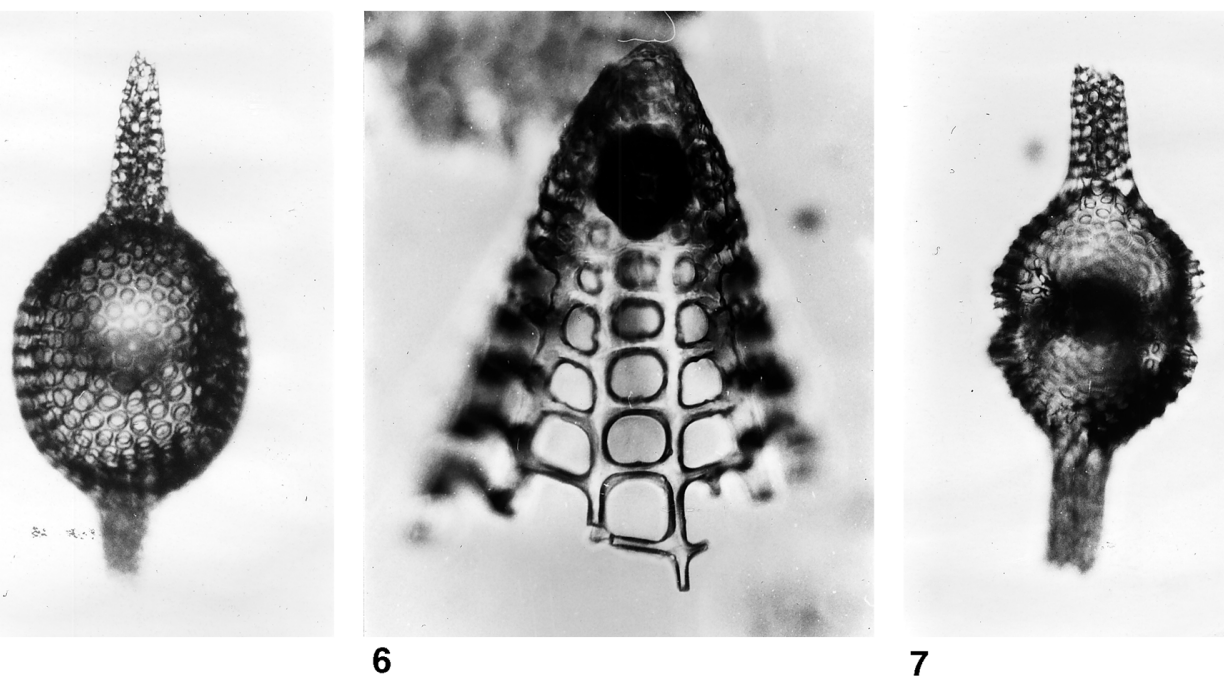

5

6

7

Plate 4. 1. Oroscena carolae Friend and Riedel, Sample 156-949B-19X-3, 79-81 cm; 41×. 2. Heliodiscus asteriscus Haeckel, Sample 156-948C-11X-2, 16-19 $\mathrm{cm}$; 205×. 3. Zygocircus productus (Hertwig) tricariantus Goll, Sample 156-949B-19X-CC; 370×. 4. Lychnocanoma elongata (Vinassa), Sample 156-948C11X-2, 16-19 cm; 250×. 5. Didymocyrtis prismatica (Haeckel), Sample 156-949B-19X-3, 79-81 cm; 205×. 6. Didymocyrtis violina (Haeckel), Sample 156949B-19X-CC; 205×. 7. Bathropyramis sp., Sample 156-949B-19X-CC; 260×. 